\title{
Ladislaus von Bortkiewicz's Errors and a Reliable Solution to the Marxian Problem of Transformation in Direct and Inverse Formulation
}

\author{
Valeriy Kalyuzhnyi
}

https://orcid.org/0000-0002-4974-5471

\section{ABSTRACT}

The paper argues that economists still regard the solution to the problem of the transformation of values into prices of production, got by L. von Bortkiewicz, as belonging to Marx himself. After all, it was allegedly "correctly corrected" by the said author in 1907. Bortkiewicz based his solution on several erroneous interpretations' theory of Marx. Because of Bortkiewicz's errors, the representatives of the mainstream see no connection between the "value system" and the "production price system". They claim that the transformation problem itself results from impossibility and that Marxist value theory is, at best, irrelevant and irremediably inconsistent. The paper shows that the solution to the transformation issue exists in both the direct and inverse formulation. We used for this purpose the Tugan-Baranovsky-Bortkiewicz three-sector model. These results are consistent with the concept of Marx within the dualistic approach. They coincide with the results generated by the author in his previous work (see https://osf.io/tk43d/). In the present paper, we introduce methods and examples of transformation, including iterative and based on solving systems of simultaneous equations. We prove again with their help that at equilibrium prices, profit arises from surplus value, or more precisely, from the newly created value generated by workers' labour and from no other source. We also show that a dualistic approach to transformation allows us to see the advantages of value prices, which, unlike production prices, do not limit the growth of the productive power of labour when enterprises introduce new machines. Value prices are in demand under socialism.
\end{abstract}

\section{KEYWORDS}

Marx; transformation problem; Bortkiewicz's solution; critique; original transformation; secondary transformation; direct transformation of values; inverse transformation of prices; methods of transformation; standard solution

\section{JEL CODES}

B14; B16; B24; B51; D58; E11; P16

\begin{abstract}
A credible solution of the value price transformation problem is the Holy Grail ${ }^{1}$ that will prove that profits come from surplus value generated by workers and from no other source. We await a rigorous proof. (Desai 2019, 64)
\end{abstract}

\section{Introduction}

By now, the literature dealing with the problem of transforming commodity values into production prices has grown to an incredible size. It is here that quantity has turned into quality. Unsuccessful attempts to solve this problem have led to claims that the 'transformation problem' is 'wretched and unnecessary' (Kurz 2018, 40). I will therefore not undertake a conventional literature review here. Partially, this review I did in my recent paper (Kalyuzhnyi 2021). This paper extends that article, as it extends the solution to the transformation problem I got earlier in the three-sector model of simple reproduction. I call this model the TuganBaranovsky-Bortkiewicz model.

\footnotetext{
${ }^{1}$ The term "holy grail" is often used to denote an elusive object or goal that is sought after for its great significance.
} 
L. von Bortkiewicz's role in researching the problem of transformation is ambiguous. He published in 1906-7 a series of papers dealing with the problem of the average rate of profit. Engels formulated this problem in the introduction to the second volume of Capital. Marx presented a solution to the problem in chapter nine of the third volume of Capital. Bortkiewicz argued that this solution was erroneous and needed correction. His correction was that in mathematical modelling of the transformation of values into production prices, he ignored one of Marx's macroeconomic equations - the sum of production prices of the entire social product must be equal to the sum of its value. He made Marx's second macroeconomic equality the main one - the sum of the profits of all the different spheres of production must be equal to the sum of surplus value. That is not all. For example, Freeman drew attention to the following:

The counter-attack spearheaded by Böhm-Bawerk led in 1897 to Komorzinsky's allegation that Marx failed to transform the 'value of constant capital'. Drawing on Dmitriev and TuganBaranowsky, von Bortkiewicz's 1906-7 response-especially following Sweezy's 1942 endorsement - became the standard for Marxists and non-Marxists alike.

Bortkiewicz did not deny the criticism but added the damning claim that internal inconsistency in Marx's procedure rendered the mistake ineradicable, justifying the substitution of his own quite distinct procedure for Marx's. Subsequent authors systematically omitted the distinction so that the construction is universally attributed to Marx, its flaws providing the justification for mainstream exclusion of Marx. A growing body of work suggests that Marx's own treatment suffers neither from the omissions nor the contradictions attributed to it, focussing renewed attention on Marx's own concept of value and price. (Freeman 2000, 2).

Many economists perceived Bortkiewicz's solution as the only correct and correction to Marx's theory. They identify this 'corrective' solution with one belonging to Marx himself. For example, Samuelson clearly expressed this view in his two famous papers (Samuelson 1970, 425; 1971, 399). I have shown that Marx does not have the transformation errors attributed to him for so long by his critics and 'correctors' (see Kalyuzhnyi 2021). We now have to show that applying Marx's transformation method to the Tugan-Baranovsky-Bortkiewicz model also leads to a solution devoid of errors, including those allegedly found by Bortkiewicz in Marx.

This paper proves Bortkiewicz fulfilled the role of a kind of Hamelin's piper in the political economy. Through his solution to the transformation problem, like magic flute, he led twentiethcentury political economists out of the temple of Marxian political economy and set them on the false path of unfounded criticism of Marx's theory. Undertaking constructive criticism of Bortkiewicz, I argue that a credible solution to the problem of transformation is possible.

\section{Bortkiewicz's main errors}

Bortkiewicz claimed invariance for the unit value of luxury goods, the products of Department III, in the traditional three-sector breakdown of the economy. He identified luxury goods with gold and thus expressed monetary prices in terms of the labour value of gold. Mark Blaug remarked: “On applying Bortkiewicz's solutions to the given value system, it appears that total surplus values are equal to total profits but that 'total values' necessarily diverge from 'total prices'." (Blaug 1985, 233). That is a consequence of the fact that the organic composition of capital in sector III is not equal to the average sectoral composition.

In criticising Marx's solution, Bortkiewicz made several fundamental errors. They are evidence of his inattentive reading of Marx's Capital. 
First, Bortkiewicz failed to realize that Marx's tables in Chapter 9 of Volume III of Capital refer to different and independent spheres of production rather than to more or less mutually dependent branches of social production (see Kalyuzhnyi 2021). These separate spheres comprise two sectors: 1) sector A, which produces the means of production for consumption within the sphere, and 2) a particular sector B, which supplies only final products to the market. Blaug understood that Marx's table referred only to sectors B: "The economy is assumed to consist of five sectors, and no product is included in the production process of another sector." (Blaug 1985, 229).

However, Blaug did not look at Marx's spheres and switched to an analysis of the threesector model. Meanwhile, Marx distinguished between spheres and branches:

Exchange does not create the differences between the spheres of production, but brings what are already different into relation, and thus converts them into more or less inter-dependent branches of the collective production of an enlarged society. In the latter case, the social division of labour arises from the exchange between spheres of production, that are originally distinct and independent of one another. ${ }^{2}$ (Marx [1867] 1996, 357)

Second, Bortkiewicz failed to understand that Marx eliminated double counting in the system of spheres of production. Marx understands the social product after this elimination as the final product, not the gross. Marx clarifies this in Chapter 49 of Volume III of Capital:

For the purposes of the following analysis we may leave out of consideration the distinction between price of production and value, since this distinction disappears altogether when, as here, the value of the total annual product of labour is considered, i.e., the product of the total social capital. (Marx [1894] 1998, 818-9)

The entire value portion of commodities, then, in which the total labour of the labourers added during one day, or one year, is realized, the total value of the annual product, created by this labour, is divided into the value of wages, into profit and into rent. (Marx [1894] 1998, 820)

Third, Bortkiewicz overlooked that Marx's transformation process of values into production prices comprises two stages. The first stage is the forming of the average rate of profit in each separate sphere of production. The second stage is the setting of the total rate of profit of particular spheres, i.e., sectors B. Marx shows only the second stage in the main transformation table. He does not reveal the content of the first stage. I have found that the above two stages can be repeated, as iterations, until all sectors $\mathrm{A}$ and $\mathrm{B}$ form a general rate of profit. This method of transformation derives from the following theoretical constructs of Marx:

The prices which obtain as the average of the various rates of profit in the different spheres of production added to the cost prices of the different spheres of production, constitute the prices of production. They have as their prerequisite the existence of a general rate of profit, and this, again, presupposes that the rates of profit in every individual sphere of production taken by itself have previously been reduced to just as many average rates. These particular rates of profit $=s / C$ in every sphere of production, and must, as occurs in Part I of this book, be deduced out of the values of the commodities. Without such deduction the general rate of profit (and consequently the price of production of commodities) remains a vague and senseless conception. (Marx [1894] 1998, 156)

... Deviations of the rates of profit in various ${ }^{3}$ spheres of production are continually balanced out into an average rate. (Marx [1894] 1998, 637)

\footnotetext{
${ }^{2}$ For emphasis in quotations, regular italics indicates emphasis in the original and bold italics indicates emphasis added by me. I add brackets in quotations unless otherwise noted.

${ }^{3}$ The German translation is "separated spheres" is more appropriate here, rather than is "various spheres" (see Marx [1894] 1904, 184).
} 
To apply such a transformation of values into prices, we must know the postulates of invariance, which define the purpose of the transformation and its limiting preconditions. Fourthly, Bortkiewicz, in his solution, ignored the crucial premise used by Marx in Chapter 9 of Volume III of Capital. It reads:

In our consideration of the transformation of surplus value into profit, we assumed that wages do not fall, but remain constant, because there we had to investigate the fluctuations in the rate of profit, independent of the changes in the rate of surplus value. (Marx [1894] 1998, 844-5)

Marx uses the postulate of the invariance of nominal wages when considering the process of the original transformation of values into prices of production. He mentions this transformation only once in Theories of surplus value:

He (Ramsay - V.K.) also brings up again Ricardo's exceptions. These latter will have to be discussed in that part of our text where we speak of the conversion of value into price of production. ${ }^{4}$ That is, very briefly, as follows. Provided that in the different trades the length of the working day (in so far as this is not compensated by the intensity of labour, the unpleasantness of the work, etc.) is the same, or rather the surplus labour is the same [as well as] the rate of exploitation, the rate of surplus value can change only if wages rise or fall. Such variations in the rate of surplus value=the rise or fall in wages, will affect the production prices of commodities in different ways according to the organic composition of capital. <..> Strictly speaking, all this hardly belongs to the discussion of the original conversion of values into production prices and the original establishment of the general rate of profit, since it is much more a question of how a general rise or fall in wages will affect production prices regulated by the general rate of profit. ${ }^{5}$ (Marx [1861-3] 1991, 261)

Marx postulates under the original conversion the invariance of the final social product, the nominal wage and, as a following, the equality of the sum of profits to the sum of surplus value. The primary effect of the original transformation is to establish the general rate of profit, with a direct change in the value of constant capital and an indirect modification of the price of variable capital. On this occasion, Marx writes:

Aside from the fact that the price of a particular product, let us say that of capital B, differs from its value because the surplus value realised in B may be greater or smaller than the profit added to the price of the products of $\mathrm{B}$, the same circumstance applies also to those commodities which form the constant part of capital B, and indirectly also its variable part, as the labourers' necessities of life. $<\ldots>$ As for the variable capital, the $<\ldots>$ one commodity receiving too little of the surplus value while another receives too much, so that the deviations from the value which are embodied in the prices of production compensate one another. (Marx [1894] 1998, 160)

It means that, because of the original transformation, a gap appears between the physical quantities of the means of life workers receive before and after the conversion of their values into

\footnotetext{
${ }^{4}$ Marx intended to address the question of the transformation of values into prices of production in the second chapter of Capital and Profit, as seen in the outline of this chapter, written shortly after the chapter on Ramsay. The Capital and Profit section later grew into Volume III of Capital.

${ }^{5}$ Marx writes about this question, which we further call the question of secondary transformation, in Chapter 10 and Chapter 11 of Volume III of Capital. From Chapter 11, we see Marx accompanies the secondary transformation by the equality of the sum of the prices and the sum of the values of the final goods. The change in wages necessary to achieve equilibrium production prices only increases (or decreases) the sum of profits. Marx calls the consideration of secondary transformation a secondary issue. (Marx [1894] 1991, 202). It means that, in his theory, the original conversion plays a primary role, of course, under the assumption of the full realization of the law of large numbers.
} 
prices. This gap is a contradiction. He can lead to a mismatch of supply and demand for workers' necessities of life, to an imbalance between production and consumption, and a partial destruction of the original pattern of simple reproduction of the social product. In Grundrisse, for example, Marx believed that the said contradiction was itself resolved by the market, which redistributes the goods produced between workers and capitalists (see Marx [1857-61] 1986, 366). However, this would mean that there is a change in real wages. In Volume III of Capital, Marx proposed a new method of eliminating contradiction, which he based on an account of the operation of the law of large numbers. It is this law that leads to the complete mutual compensation of positive and negative deviations of prices from values. We see the new method in the above quotation.

Economists, through empirical studies, have confirmed the validity of this method. For example, Shaikh has shown that in actual conditions price aggregates are essentially equivalent to corresponding labour value aggregates. (Shaikh 2021, 375-7).

Fifthly, Bortkiewicz interpreted Marx's main transformation table as presenting an ultimate solution to the problem of the average rate of profit. That is a misinterpretation. Marx's table solution represents only the initial stage of the iterative transformation of values into prices. This stage illustrates the formation of the general rate of profit in the spheres of production, which Marx had previously cleared from the double counting of profits and wages (Kalyuzhnyi 2021). Shaikh (2021, 368-9) also came to a close conclusion:

...In Marx's presentation of his algorithm, he is careful to state that it is a first step because any deviations of prices from values implies that costs previously expressed in labor value terms must be further adjusted to reflect the new prices. $<\ldots>$ In other words, his derivation is the beginning of an iterative process. Iteration has been around since Gauss (1823), and even today is commonly utilized in computer calculations. The steps involved could easily have been implemented by Marx, and have been shown to lead to the standard simultaneous equation solution (Shaikh 1977; Morishima and Catephores 1978).

Marx could indeed have realized an iterative process if he had considered industries rather than spheres of production in his transformation table. But Marx was looking at particular spheres of production. To realize the iterative process, he would first have had to restore the double counting in this table and consider the separate spheres of production (see Kalyuzhnyi 2021). Applying the iterative procedure directly to Bortkiewicz's model, and under the assumptions he used, can lead to a standard solution of the simultaneous equations. However, to apply Marx's method to Bortkiewicz's model, we must transform it into a model of independent (separate) spheres of production. We can then employ an iterative process of original or, if necessary, secondary transformation.

Bortkiewicz proposed a method for the solution of the transformation problem. Bortkiewicz's procedure relies on the invariance of real wages and the equality between the sum of profit and the sum of surplus value. But Marx used the postulate of invariance of real wages in chapter 11 of volume III of Capital. He implied he was investigating the secondary question of "how a general rise or fall in wages would affect the prices of production governed by the general rate of profit." (Marx [1861-3] 1991, 261)

Marx described the method of addressing this question in chapter 10 of volume III of Capital (see Marx [1894] 1998, 178-9). Marx thought that the original prices of workers' consumption goods could be disequilibrium. Here, the demand and supply of goods do not coincide with each other. We can re-establish equilibrium by changing the wages and prices of the goods that make up permanent capital. But we can get balance because of the law of large numbers. Then the original prices of production become equilibrium. Here, there is no need for a secondary transformation. 


\section{Transformation of values into prices under Marx's concept}

To transform values into prices, Bortkiewicz used the Tugan-Baranowsky model in value prices (see Table 1, subsection 1.1). He applied the purported "Marx method" to this construction (Table 1, subsection 1.2) and got a pronounced non-equilibrium solution. On this basis, Bortkiewicz gave a 'death sentence' to Marx's solution by presenting an alternative solution (Table 1, subsection 1.3). ${ }^{6}$

Table 1. Simple reproduction model transformed by Bortkiewicz into production prices using the "Marx method" (Bortkiewicz 1907b: 324)

\begin{tabular}{|c|c|c|c|c|c|c|}
\hline \multicolumn{7}{|c|}{ 1.1. Initial Model in Value Prices } \\
\hline \multirow{2}{*}{ Branches } & $\begin{array}{c}\text { Constant } \\
\text { Capital }\end{array}$ & $\begin{array}{c}\text { Variable } \\
\text { Capital }\end{array}$ & $\begin{array}{l}\text { Surplus } \\
\text { Value }\end{array}$ & Value & $\begin{array}{l}\text { General Rate of } \\
\text { Surplus Value }\end{array}$ & Rate of Profit \\
\hline & $c_{i}$ & $v_{i}$ & $m_{i}$ & $w_{i}=c_{i}+v_{i}+m_{i}$ & $\sigma=m_{i} / v_{i}$ & $r_{i}=m_{i} /\left(c_{i}+v_{i}\right)$ \\
\hline I & 225 & 90 & 60 & 375 & $66.67 \%$ & $19.05 \%$ \\
\hline II & 100 & 120 & 80 & 300 & $66.67 \%$ & $36.36 \%$ \\
\hline III & 50 & 90 & 60 & 200 & $66.67 \%$ & $42.86 \%$ \\
\hline Total & 375 & 300 & 200 & 875 & $66.67 \%$ & $29.63 \%$ \\
\hline \multicolumn{4}{|c|}{ Average Rate of Profit: } & \multicolumn{3}{|c|}{$\bar{r}=200 m /(375 c+300 v) \cong \mathbf{2 9 . 6 3 \%}$} \\
\hline \multicolumn{7}{|c|}{ 1.2. Transformed Model in Production Prices "According to Marx" } \\
\hline \multirow[t]{2}{*}{ Branches } & $\begin{array}{c}\text { Constant } \\
\text { Capital } \\
\end{array}$ & $\begin{array}{l}\text { Variable } \\
\text { Capital } \\
\end{array}$ & $\begin{array}{l}\text { Average } \\
\text { Profit } \\
\end{array}$ & $\begin{array}{c}\text { Prices of } \\
\text { Production }\end{array}$ & $\begin{array}{l}\text { Rate of Surplus } \\
\text { Value }\end{array}$ & $\begin{array}{l}\text { Average Rate of } \\
\text { Profit }\end{array}$ \\
\hline & $c_{i}$ & $v_{i}$ & $\bar{m}_{i}$ & $\bar{w}_{i}=c_{i}+v_{i}+\bar{m}_{i}$ & $\bar{\sigma}_{i}=\bar{m}_{i} / v_{i}$ & $\bar{r} \cong 29.63 \%$ \\
\hline I & 225 & 90 & 93.333 & 408.333 & $103.70 \%$ & $29.63 \%$ \\
\hline II & 100 & 120 & 65.185 & 285.185 & $54.32 \%$ & $29.63 \%$ \\
\hline III & 50 & 90 & 41.482 & 181.482 & $46.09 \%$ & $29.63 \%$ \\
\hline Total & 375 & 300 & 200 & 875 & $66.67 \%$ & $29.63 \%$ \\
\hline \multicolumn{7}{|c|}{ 1.3. Transformed Model in Production Prices According to Bortkiewicz } \\
\hline \multirow[t]{2}{*}{ Branches } & $\begin{array}{c}\text { Constant } \\
\text { Capital }\end{array}$ & $\begin{array}{l}\text { Variable } \\
\text { Capital }\end{array}$ & Profit & $\begin{array}{l}\text { Prices of } \\
\text { Production }\end{array}$ & $\begin{array}{c}\text { Rate of Surplus } \\
\text { Value }\end{array}$ & $\begin{array}{c}\text { General Rate of } \\
\text { Profit }\end{array}$ \\
\hline & $c_{i}^{\prime}$ & $v_{i}^{\prime}$ & $p_{i}$ & $w_{i}^{\prime}=c_{i}^{\prime}+v_{i}^{\prime}+p_{i}$ & $\sigma_{i}^{\prime}=p_{i} / v_{i}^{\prime}$ & $r_{i}=p_{i} /\left(c_{i}^{\prime}+v_{i}^{\prime}\right)$ \\
\hline $\mathrm{I}$ & 288 & 96 & 96 & 480 & $100.00 \%$ & $25 \%$ \\
\hline II & 128 & 128 & 64 & 320 & $50.00 \%$ & $25 \%$ \\
\hline III & 64 & 96 & 40 & 200 & $41.67 \%$ & $25 \%$ \\
\hline Total & 480 & 320 & 200 & 1000 & $62.50 \%$ & $25 \%$ \\
\hline
\end{tabular}

It is easy to see that Bortkiewicz has attributed to Marx a method of transformation that he never used in relation to interdependent branches of economic. In a paper (Kalyuzhnyi 2021), I showed Marx applied his method to separate and particular spheres of production. ${ }^{7}$

To use the Marxian transformation method, we first re-establish double counting in his model (we add sectors $A_{j}$ ). We then apply a two-stage iterative procedure to transform values into prices of production. In the first step, we establish the average rate of profit in the separate spheres of production consisting of sectors $A_{j}$ and $B_{j}$. In the second step, we form the general rate of profit for sectors $B_{j}$. The formation of the total rate of profit in sectors $B_{j}$ leads to differential rates of profit in sectors $A_{j}$ and $B_{j}$. Therefore, we further iterate the transformation procedure in

\footnotetext{
${ }^{6}$ We will refer further to the numbered subsections of the tables as Table 1.1, Table 1.2 and so on.

${ }^{7}$ The separate spheres of production include the interrelated sectors $A_{j}$ and $B_{j}$, producing intermediate and final products, respectively. I refer to the particular spheres as sectors $B_{j}$, i.e. the result of Marx's purification of the separate spheres from double counting.
} 
all separate spheres of production again. Then we set a new general rate of profit for the particular spheres of production. We end this transformation procedure once we have established the same (general) rate of profit in all sectors, $A_{j}$ and $B_{j}$, with a predetermined or maximum degree of accuracy.

A similar procedure applies both when using the postulates of invariance of the original and the secondary transformation. In the first case, we equate the production price of the final social product with its value and do not change the amount of the total wage. ${ }^{8}$ For the secondary transformation, we additionally introduce an index of change in the value of variable capital; in this way, we ensure that the real wage is constant.

We can apply the Tugan-Baranovsky-Bortkiewicz three-sector simple reproduction model for the calculations described above. First, we must convert this model into a reproduction model with two spheres of production with two sectors each. The relevant procedure of model transformation I have described in the paper (Kalyuzhnyi 2006). I give the results in Table 2.

Table 2 shows that the model now comprises two sub-systems of final product production. This model results from an elementary allocation of the product of industry I (production of the means of production) to industries II (production of wage goods) and III (production of luxury goods). We end up with two separate spheres of production or subsystems comprising sectors $\left(\mathrm{A}_{1}\right.$ and $\left.\mathrm{B}_{1}\right)$ and $\left(A_{2}\right.$ and $\left.B_{2}\right)$. They produce two final products: consumption goods for workers $\left(B_{1}\right)$ and consumption goods for capitalists $\left(\mathrm{B}_{2}\right)$. That corresponds to Sraffa's idea of sub-systems. He wrote we could divide the system of industries that make up the gross product into parts, with into as many parts as there are goods in its net product, so that each part forms a smaller selfsubstituting system whose net product comprises only one kind of good. These parts we shall call 'sub- systems'. (Sraffa 1960, 89).

Table 2. Transforming the Tugan-Baranovsky-Bortkiewicz's three-sector model into two sub-systems of final product production

\begin{tabular}{|c|l|l|c|c|c|c|c|c|}
\hline \multicolumn{2}{|c|}{$\begin{array}{c}\text { Sphere, } \\
\text { Sector }\end{array}$} & $\begin{array}{c}\text { Gross Output } \\
\text { Structure }\end{array}$ & $\begin{array}{c}\text { Constant } \\
\text { Capital }\end{array}$ & $\begin{array}{c}\text { Variable } \\
\text { Capital }\end{array}$ & $\begin{array}{c}\text { Surplus } \\
\text { Value }\end{array}$ & $\begin{array}{c}\text { Value of } \\
\text { Product }\end{array}$ & $\begin{array}{c}\text { Rate of } \\
\text { Surplus } \\
\text { Value }\end{array}$ & $\begin{array}{c}\text { General Rate } \\
\text { of Profit }\end{array}$ \\
\cline { 4 - 9 } & & $c_{i}$ & $v_{i}$ & $m_{i}$ & $w_{i}=c_{i}+v_{i}+m_{i}$ & $\sigma=m_{i} / v_{i}$ & $r=m_{i} /\left(c_{i}+v_{i}\right)$ \\
\hline \multirow{2}{*}{1} & $\mathrm{~A}_{1}$ & Means of production & 150 & 60 & 40 & 250 & $66.667 \%$ & $19.048 \%$ \\
\cline { 3 - 9 } & $\mathrm{B}_{1}$ & Final product & 100 & 120 & 80 & 300 & $66.667 \%$ & $36.364 \%$ \\
\hline \multirow{2}{*}{2} & $\mathrm{~A}_{2}$ & Means of production & 75 & 30 & 20 & 125 & $66.667 \%$ & $19.048 \%$ \\
\cline { 2 - 9 } & $\mathrm{B}_{2}$ & Final product & 50 & 90 & 60 & 200 & $66.667 \%$ & $42.857 \%$ \\
\hline \multirow{2}{*}{ Sum } & \multirow{2}{*}{ Sum } & Means of production & 225 & 90 & 60 & 375 & $66.667 \%$ & $19.048 \%$ \\
\cline { 2 - 9 } & Total final product & 150 & 210 & 140 & 500 & $66.667 \%$ & $38.889 \%$ \\
\cline { 2 - 9 } & Gross output & 375 & 300 & 200 & 875 & $66.667 \%$ & $29.630 \%$ \\
\hline
\end{tabular}

A sub-system "is a vertically integrated 'slice' of the economy that produces a single commodity as final output and replaces the used-up means of production." (Wright 2019, 171).

Thus, we have decomposed the Tugan-Baranovsky-Bortkiewicz's model of simple reproduction into two sub-systems, each producing one commodity as the final product and reproducing the means of production used in it. Either sub-system, which we call a separate sphere of production, we can represent as Marx's model of simple reproduction:

\footnotetext{
${ }^{8}$ After the original transformation, the sum of the profits of all sectors $\mathrm{Aj}$ and $\mathrm{Bj}$ is equal to the sum of their surplus value, and the total final product of all sectors $\mathrm{Bj}$ in prices of production and in value is equal to each other.
} 


$$
\left.\begin{array}{l}
c_{\mathrm{Aj}}+v_{\mathrm{Aj}}+m_{\mathrm{Aj}}=w_{\mathrm{Aj}} \\
c_{\mathrm{Bj}}+v_{\mathrm{Bj}}+m_{\mathrm{Bj}}=w_{\mathrm{Bj}}
\end{array}\right\}
$$

Where $w_{\mathrm{Aj}}$ and $w_{\mathrm{Bj}}$ are the value of the output of sectors $\mathrm{A}$ and $\mathrm{B}$ of sphere $\mathrm{j} ; c_{\mathrm{Aj}}$ and $c_{\mathrm{Bj}}$ are the value of constant capital of sectors $A$ and $B$ of sphere $j$; capital of sectors $A$ and $B$ of sphere $\mathrm{j} ; v_{\mathrm{Aj}}$ and $v_{\mathrm{Bj}}$ are the value of a variable capital of sectors $\mathrm{A}$ and $\mathrm{B}$ of sphere $\mathrm{j}$.

Sectors $A_{j}$ produce the means of production (constant capital) to the extent necessary to meet the demand of the separate sphere, i.e.

$$
w_{\mathrm{Aj}}=c_{\mathrm{Aj}}+c_{\mathrm{Bj}}
$$

Sectors $\mathrm{B}_{\mathrm{j}}$ produce final products for commodity exchange with other separate spheres. Marx writes in Volume II of Capital

that, on the basis of simple reproduction, the sum of the values of $v+m$ of the commodity capital of I (and therefore a corresponding proportional part of the total commodity product of must be equal to the constant capital IIc, which is likewise taken as a proportional part of the total commodity product of department II; I $(v+m)=$ IIc. $($ Marx [1885] 1997, 401)

We analyse the data in Table 2 and see that Marx's equality $\mathrm{I}(\mathrm{v}+\mathrm{m})=\mathrm{II}_{\mathrm{c}}$ is fulfilled in some areas, as it follows from (1) and (2) that

$$
c_{\mathrm{Bj}}=w_{\mathrm{Aj}}-c_{\mathrm{Aj}}=v_{\mathrm{Aj}}+m_{\mathrm{Aj}}
$$

According to Marx's procedure, we must first align the differential rates of profit of sectors $A_{j}$ and $B_{j}$ in each separate sphere of production into an average rate of profit and then carry out an alignment of the rates of profit of sectors $B_{j}$. We determine an index of change in the price of permanent capital, which ensures equalisation of the rates of profit in the separate sphere, based on the following modification of model (1):

$$
\left.\begin{array}{l}
c_{\mathrm{Ajt}} x_{\mathrm{jt}+1}+v_{\mathrm{Ajt}}+m_{\mathrm{Ajt}}=w_{\mathrm{Ajt}} x_{\mathrm{jt}+1} \\
c_{\mathrm{Bjt}} x_{\mathrm{jt}+1}+v_{\mathrm{Bjt}}+m_{\mathrm{Bjt}}=w_{\mathrm{Bjt}}
\end{array}\right\}
$$

We determine the index $x_{\mathrm{jt+1}}$ after transforming system (4) into equality:

$$
\frac{w_{\mathrm{Ajt}} x_{\mathrm{jt}+1}-\left(c_{\mathrm{Aj}} x_{\mathrm{jt}+1}+v_{\mathrm{Ajt}}\right)}{\left(c_{\mathrm{Ajt}} x_{\mathrm{jt}+1}+v_{\mathrm{Ajt}}\right)}=\frac{w_{\mathrm{Bjt}}-\left(c_{\mathrm{Bjt}} x_{\mathrm{jt}+1}+v_{\mathrm{Bjt}}\right)}{\left(c_{\mathrm{Bjt}} x_{\mathrm{jt}+1}+v_{\mathrm{Bjt}}\right)} \text {. }
$$

The left-hand side of equality (5) represents the rate of profit of sector A and the right-hand side of sector B. We define from (5) the following formula to calculate the magnitude of index $x_{\mathrm{jt}+1}$ :

$$
x_{\mathrm{jt}+1}=\frac{\left(w_{\mathrm{Bjt}} c_{\mathrm{Ajt}}-w_{\mathrm{Ajt}} v_{\mathrm{Bjt}}\right)+\sqrt{\left.\left(w_{\mathrm{Ajt}} v_{\mathrm{Bjt}}-w_{\mathrm{Bjt}} c_{\mathrm{Ajt}}\right)^{2}+4 w_{\mathrm{Ajt}} c_{\mathrm{Bjt}} w_{\mathrm{Bjt}} v_{\mathrm{Ajt}}\right)}}{2 w_{\mathrm{Ajt}} c_{\mathrm{Bjt}}},
$$

We calculated the $x_{\mathrm{jt}+1}$ indices using the numerical data from Table 2. They gave the following result: $x_{\mathrm{I}}=1.2$ and $x_{\mathrm{II}}=1.324695077$. We then easily obtain the transformation result we present in Table 3.1.

This result means that, by Marx's indication, “...the profit rates in each particular sphere of production, taken by itself, are already reduced to their average rates." (Marx [1894] 1991, 257). We can therefore proceed to the next step in Marx's procedure and establish in the particular spheres of production (sectors $\mathrm{B}_{1}$ and $\mathrm{B}_{2}$ ) a general rate of profit equal to the average rate of profit got in the previous step of the transformation, i.e. $r \cong 26.188 \%$. 
Table 3. Stages of the iterative transformation of values into product prices of sectors and spheres of production sub-systems (under the postulates of invariance of the original conversion)

\begin{tabular}{|c|l|l|c|c|c|c|c|c|}
\hline $\begin{array}{c}\text { Sphere, } \\
\text { Sector }\end{array}$ & $\begin{array}{c}\text { Gross Output } \\
\text { Structure }\end{array}$ & $\begin{array}{c}\text { Constant } \\
\text { Capital }\end{array}$ & $\begin{array}{c}\text { Variable } \\
\text { Capital }\end{array}$ & $\begin{array}{c}\text { Surplus } \\
\text { Value }\end{array}$ & $\begin{array}{c}\text { Value of } \\
\text { Product }\end{array}$ & $\begin{array}{c}\text { Rate of } \\
\text { Surplus Value }\end{array}$ & $\begin{array}{c}\text { Rate of } \\
\text { Profit }\end{array}$ \\
\hline \multicolumn{2}{|c|}{ 3.1. Stage one: Formation of average rates of profit in sectors of separate spheres 1 and 2 } \\
\hline \multirow{2}{*}{1} & $\mathrm{~A}_{1}$ & Means of production & 180 & 60 & 60 & 300 & $100.000 \%$ & $25 \%$ \\
\cline { 2 - 9 } & $\mathrm{B}_{1}$ & Final product & 120 & 120 & 60 & 300 & $50.000 \%$ & $25 \%$ \\
\hline \multirow{2}{*}{2} & $\mathrm{~A}_{2}$ & Means of production & 99.352 & 30 & 36.235 & 165.587 & $120.783 \%$ & $28.012 \%$ \\
\cline { 2 - 9 } & $\mathrm{B}_{2}$ & Final product & 66.235 & 90 & 43.765 & 200 & $48.628 \%$ & $28.012 \%$ \\
\hline \multirow{2}{*}{ Sum } & \multirow{2}{*}{ Sum } & Means of production & 279.352 & 90 & 96.235 & 465.587 & $106.928 \%$ & $26.055 \%$ \\
\cline { 2 - 9 } & Total final product & 186.235 & 210 & 103.765 & 500 & $49.412 \%$ & $\mathbf{2 6 . 1 8 8 \%}$ \\
\cline { 2 - 9 } & Gross output & 465.587 & 300 & 200 & 965.587 & $66.667 \%$ & $26.124 \%$ \\
\hline
\end{tabular}

\begin{tabular}{|c|c|c|c|c|c|c|c|c|}
\hline \multicolumn{9}{|c|}{ 3.2. Second stage: Formation of general rates of profit in sectors $\mathrm{B} 1$ and $\mathrm{B} 2$} \\
\hline \multirow{2}{*}{1} & $\mathrm{~A}_{1}$ & Means of production & 180 & 60 & 60 & 300 & $100.000 \%$ & $25.000 \%$ \\
\hline & $\mathrm{B}_{1}$ & Final product & 120 & 120 & 62.851 & 302.851 & $52.376 \%$ & $26.188 \%$ \\
\hline \multirow{2}{*}{2} & $\mathrm{~A}_{2}$ & Means of production & 99.352 & 30 & 36.235 & 165.587 & $120.783 \%$ & $28.012 \%$ \\
\hline & $\mathrm{B}_{2}$ & Final product & 66.235 & 90 & 40.914 & 197.149 & $45.461 \%$ & $26.188 \%$ \\
\hline \multirow{3}{*}{\multicolumn{2}{|c|}{ Sum }} & Means of production & 279.352 & 90 & 96.235 & 465.587 & $106.928 \%$ & $26.055 \%$ \\
\hline & & Total final product & 186.235 & 210 & 103.765 & 500 & $49.412 \%$ & $26.188 \%$ \\
\hline & & Gross output & 465.587 & 300 & 200 & 965.587 & $66.667 \%$ & $26.124 \%$ \\
\hline
\end{tabular}

3.3 The final stage of iterations: Formation of the general rate of profit in all sectors of the separate spheres of production

\begin{tabular}{|c|c|c|c|c|c|c|c|c|}
\hline \multirow{2}{*}{1} & $\mathrm{~A}_{1}$ & Means of production & 186.510 & 60 & 64.340 & 310.850 & $107.233 \%$ & $26.1003 \%$ \\
\hline & $\mathrm{B}_{1}$ & Final product & 124.340 & 120 & 63.773 & 308.113 & $53.145 \%$ & $26.1003 \%$ \\
\hline \multirow{2}{*}{2} & $\mathrm{~A}_{2}$ & Means of production & 93.255 & 30 & 32.170 & 155.425 & $107.233 \%$ & $26.1003 \%$ \\
\hline & $\mathrm{B}_{2}$ & Final product & 62.170 & 90 & 39.717 & 191.887 & $44.130 \%$ & $26.1003 \%$ \\
\hline \multirow{3}{*}{\multicolumn{2}{|c|}{ Sum }} & Means of production & 279.765 & 90 & 96.510 & 466.274 & $107.233 \%$ & $26.1003 \%$ \\
\hline & & Total final product & 186.510 & 210 & 103.490 & 500.000 & $49.281 \%$ & $26.1003 \%$ \\
\hline & & Gross output & 466.274 & 300 & 200 & 966.274 & $66.667 \%$ & $26.1003 \%$ \\
\hline
\end{tabular}

We show the result in Table 3.2. The data in Table 3.2 show that after the emergence of a general rate of profit in sectors $\mathrm{B}_{1}$ and $\mathrm{B}_{2}$, the considered procedure restores the differentiation of profit rates between sectors $A_{j}$ and $B_{j}$. However, we noticeably reduce the magnitude of the rate differentiation. For example, before the transformation process began, the difference between the profit rates in sphere 1 was $36.364-19.048=17.360 \%$ (see Table 2). This difference decreased after the first iteration to $26.188-25=1.188 \%$ (see Table 3.2). I developed a program for Excel (Kalyuzhnyi 2021a), which automatically performs 70 iteration steps. We have given the last iteration step in Table 3.3 and can convert it into a three-sector model. We present the result in Table 4.

We can also perform the original conversion of value into production prices by solving a system of simultaneous equations. For example, we can determine the price index of constant capital $k_{1}$ and the general rate of profit $r^{\prime}$ from the following system of equations (see Kalyuzhnyi 2014, 14): 


$$
\left.\begin{array}{l}
w_{1} k_{1}=c_{1} k_{1}+v_{1}+r^{\prime}\left(c_{1} k_{1}+v_{1}\right) \\
r^{\prime}=\Sigma m_{i} /\left(k_{1} \Sigma c_{i}+\Sigma v_{i}\right)
\end{array}\right\} .
$$

We can solve the system of equations (7) using the data $w_{1}, c_{1}, v_{1}, \Sigma v_{i}$ and $\Sigma m_{i}$ using the following formulas:

$$
\begin{aligned}
& k_{1}=\left(-b \pm \sqrt{b^{2}-4 a c}\right) / 2 a=1.24339811320566, \text { where } a=\Sigma c_{i}\left(w_{1}-c_{1}\right)=56250 ; \\
b= & \left(w_{1} \Sigma v_{i}-c_{1} \Sigma v_{i}-v_{1} \Sigma c_{i}-\Sigma m_{i} c_{1}\right)=-33750 \text { and } c=-v_{1}\left(\Sigma v_{i}+\Sigma m_{i}\right)=-45000 . \\
& r^{\prime}=\Sigma m_{i} /\left(k_{1} \Sigma c_{i}+\Sigma v_{i}\right)=0.261003144657233 .
\end{aligned}
$$

After that, we define:

\begin{tabular}{|c|c|c|c|c|c|c|}
\hline \multicolumn{7}{|c|}{ 4.1. Initial Model in Value Prices } \\
\hline \multirow{2}{*}{ Branches } & $\begin{array}{c}\text { Constant } \\
\text { Capital }\end{array}$ & $\begin{array}{l}\text { Variable } \\
\text { Capital } \\
\end{array}$ & $\begin{array}{c}\text { Surplus } \\
\text { Value }\end{array}$ & Value & $\begin{array}{c}\text { Rate of Surplus } \\
\text { Value }\end{array}$ & Rate of Profit \\
\hline & $c_{i}$ & $v_{i}$ & $m_{i}$ & $w_{i}=c_{i}+v_{i}+m_{i}$ & $\sigma=m_{i} / v_{i}$ & $r_{i}=m_{i} /\left(c_{i}+v_{i}\right)$ \\
\hline $\mathrm{I}$ & 225 & 90 & 60 & 375 & $66.667 \%$ & $19.048 \%$ \\
\hline II & 100 & 120 & 80 & 300 & $66.667 \%$ & $36.364 \%$ \\
\hline III & 50 & 90 & 60 & 200 & $66.667 \%$ & $42.857 \%$ \\
\hline Total & 375 & 300 & 200 & 875 & $66.667 \%$ & $29.630 \%$ \\
\hline \multicolumn{7}{|c|}{ 4.2. Transformed Model in Production Prices According to Marx } \\
\hline \multirow{2}{*}{ Branches } & $\begin{array}{c}\text { Constant } \\
\text { Capital }\end{array}$ & $\begin{array}{l}\text { Variable } \\
\text { Capital } \\
\end{array}$ & Profit & $\begin{array}{c}\text { Original Prices } \\
\text { of Production }\end{array}$ & $\begin{array}{c}\text { Rate of Surplus } \\
\text { Value }\end{array}$ & $\begin{array}{c}\text { General Rate of } \\
\text { Profit }\end{array}$ \\
\hline & $c_{i}^{\prime}$ & $v_{i}$ & $p_{i}^{\prime}$ & $w_{i}^{\prime}=c_{i}^{\prime}+v_{i}+p_{i}^{\prime}$ & $\sigma^{\prime}=p_{i}^{\prime} / v_{i}$ & $r_{i}^{\prime}=p_{i}^{\prime} /\left(c_{i}^{\prime}+v_{i}\right)$ \\
\hline I & 279.765 & 90 & 96.510 & 466.274 & $107.233 \%$ & $26.1003 \%$ \\
\hline II & 124.340 & 120 & 63.773 & 308.113 & $53.145 \%$ & $26.1003 \%$ \\
\hline III & 62.170 & 90 & 39.717 & $\mathbf{1 9 1 . 8 8 7}$ & $44.130 \%$ & $26.1003 \%$ \\
\hline Total & 466.274 & 300 & 200 & 966.274 & $66.667 \%$ & $26.1003 \%$ \\
\hline
\end{tabular}

$$
\begin{aligned}
& w_{1}^{\prime}=w_{1} k_{1} \cong 466.274 ; w_{2}^{\prime}=w_{2} k_{2}=c_{2} k_{1}+v_{2}+r^{\prime}\left(c_{2} k_{1}+v_{2}\right) \cong 308.1133 ; k_{2}=w_{2}^{\prime} / w_{2} \cong 1.0270 ; \\
& w_{3}^{\prime}=w_{3} k_{3}=c_{3} k_{1}+v_{3}+r^{\prime}\left(c_{3} k_{1}+v_{3}\right) \cong 191.8867 ; k_{3}=w_{3}^{\prime} / w_{3} \cong 0.9594 .
\end{aligned}
$$

Table 4. Simple reproduction model transformed into production prices using the Marx method original transformation

We see that the solution using the system of equations (7) coincides with the results of calculations by the iterative method presented in Table 4.2.

Note that they coincide with the results obtained by the iterated method by Glick and Ehrbar (Glick and Ehrbar 1987,309) and with the results of solving the system of simultaneous equations obtained by Rieu (Rieu 2006, 265). These authors analysed the solution under the invariance postulates of the New Interpretation. Note that the iterative method of Glick and Ehrbar differs from my method discussed above. These authors did not use the preliminary transformation of the Bortkiewicz model into two separate spheres of production. They applied a method of successive modification of the value of the three sectors of the economy.

The authors and supporters of the "New Interpretation" can now check that their result coincides with the Marxian solution. We justify these solutions by the premise that there is a full realization of the law of large numbers. In other words, we must use a sufficiently large number of commodities and capitals with different organic compositions when modelling. 


\section{Marx's method of secondary transformation and its relation to L. von Bortkiewicz's solution}

Marx showed that there is a method of secondary transformation of the original prices of production into equilibrium prices. Real wages remain the same at equilibrium prices as in the initial value model (see Table 4.1). In Chapter 10 of Volume III of Capital, Marx shows how to do this:

... The rise in commodity prices caused by an increase of the average profit must correspond to the rise of the money expression of the variable capital. Such a general nominal increase in the rate of profit and the average profit above the limit provided by the ratio of the actual surplus value to the total invested capital is not, in effect, possible without causing an increase in wages, and also an increase in the prices of commodities forming the constant capital. The reverse is true in case of a reduction. (Marx [1894] 1998, 178-9)

If we pay attention to the result of the original transformation (see Table 4.2), we notice that the general rate of profit $=26.1003 \%$ is too high because it reduces the real wage by $2.6 \%$. Hence, according to Marx, we will recover the real wage if we increase its money expression and change the price of permanent capital accordingly.

It follows from this indication by Marx that in the secondary transformation, we must suppose the sum of the prices of final goods equal to the sum of their values as a given magnitude. We can then investigate the effect of the change in total wages on total profits and real wages. We present the result of the secondary transformation by successive iterative calculations in Table 5 .

Table 5. Simple Reproduction Model Transformed into Production Prices using the Marx Method Secondary Transformation

\begin{tabular}{|c|c|c|c|c|c|c|}
\hline \multirow{2}{*}{ Branches } & $\begin{array}{c}\text { Constant } \\
\text { Capital }\end{array}$ & $\begin{array}{c}\text { Variable } \\
\text { Capital }\end{array}$ & Profit & $\begin{array}{c}\text { Secondary Prices } \\
\text { of Production }\end{array}$ & $\begin{array}{c}\text { Rate of Surplus } \\
\text { Value, \% }\end{array}$ & $\begin{array}{c}\text { General Rate of } \\
\text { Profit, \% }\end{array}$ \\
\cline { 2 - 7 } & $c_{i}^{\prime \prime}$ & $v_{i}^{\prime \prime}$ & $p_{i}^{\prime \prime}$ & $\omega_{i}^{\prime \prime}$ & $\sigma_{i}^{\prime \prime}=p_{i}^{\prime \prime} / v_{i}^{\prime \prime}$ & $r^{\prime \prime}=p_{i}^{\prime \prime} /\left(c_{i}^{\prime \prime}+v_{i}^{\prime \prime}\right)$ \\
\hline I & 276.923 & 92.308 & 92.308 & $\mathbf{4 6 1 . 5 3 8}$ & $100 \%$ & $25 \%$ \\
\hline II & 123.077 & 123.077 & 61.538 & $\mathbf{3 0 7 . 6 9 2}$ & $50 \%$ & $25 \%$ \\
\hline III & 61.538 & 92.308 & 38.462 & $\mathbf{1 9 2 . 3 0 8}$ & $41.667 \%$ & $25 \%$ \\
\hline Total & $\mathbf{4 6 1 . 5 3 8}$ & $\mathbf{3 0 7 . 6 9 2}$ & $\mathbf{1 9 2 . 3 0 8}$ & 961.538 & $62.5 \%$ & $25 \%$ \\
\hline
\end{tabular}

The data in Table 5 show that as a result of the secondary transformation, carried out in strict correspondence with Marx's postulate of invariance $\Sigma v_{i}+\Sigma s_{i}=\Sigma v_{i}^{\prime \prime}+\Sigma p_{i}^{\prime \prime}$, the sum of prices of final products of particular spheres of production equals the sum of initial values of these products, i.e. $\Sigma v_{i}+\Sigma s_{i}=\Sigma v_{i}^{\prime \prime}+\Sigma p_{i}^{\prime \prime}=307.692+192.308=300+200=500$. Here, we obtain the equilibrium prices of all branches of production by fulfilling the balance equations $\omega_{1}^{\prime \prime}=\Sigma c_{i}^{\prime \prime}$, $\omega_{2}^{\prime \prime}=\Sigma v_{i}^{\prime \prime}$ and $\omega_{3}^{\prime \prime}=\Sigma p_{i}^{\prime \prime}$.

Marx wrote that the price of production of goods produced by middle capital coincides with their value. The production price of these goods would not change under the secondary transformation. According to Marx, "...wage increase would ... have caused a drop in profit, but no change in the value and price of the commodities." (Marx [1894] 1998, 198). We consider the secondary transformation of the values of the totality of all final goods produced by average capital equal to $\left(100 c_{2}+120 v_{2}\right)+\left(50 c_{3}+90 v_{3}\right)=360$ (see Table 4.1). Under the above assumptions, the sum of wages increases by 7.692 monetary units in the example analysed, and the sum of profits decreases by the same magnitude. As a result, the sum of production prices of the total final social product is equal to the sum of its value. 
It also means that after the secondary transformation, we do not fulfil one of Marx's macroeconomic equalities, namely that the sum of the profits of all the different branches of production does not equal the sum of surplus value, i.e., $\Sigma p_{i}^{\prime \prime} \neq \Sigma s_{i}$ or $192.308<200$. However, we do not need this equality in the secondary (equilibrium) transformation. Marx replaces this equality with the equality between the sum of workers' wages and their aggregate price of commodities, i.e., $\Sigma v_{i}^{\prime \prime}=\omega_{2}^{\prime \prime}$. This equality means that the real wages and the actual degree of exploitation of labour power remain unchanged before and after the secondary transformation.

However, visible the degree of exploitation of labour power of $\sigma_{i}^{\prime \prime}=62.5 \%$ (see Table 5) is no longer the same as the actual (exact) degree of exploitation of labour power of $\sigma=m / v=$ $66,67 \%$ (see Table 1.1 or 4.1 ).

The content of Chapter 11 of Volume II of Capital allows us to sort out the issue. In particular, Tugan-Baranovsky was the first to encounter a change in the visible degree of exploitation of labour power when he considered the reverse transformation of the prices of the production of goods into their value. However, because he failed to grasp the distinction between original and secondary transformation, Tugan-Baranovsky drew several erroneous conclusions:

Marx's assertion that "the deviations of (labour-) value inherent in the production prices of commodities cancel each other out" is thus mistaken in that such a thing is only true concerning the whole of the social product, but not about its divisions into social capital and profit, by which the level of the social rate of profit is determined. (Tugan-Baranovsky 1905, 174)

Thus Marx's whole theory of profit collapses in ruins: the "vulgar economy", which regarded the whole of capital equally as a source of profit, was right. (Tugan-Baranovsky 1905, 188)

Bortkiewicz also encountered a simultaneous failure to fulfil Marx's two macroeconomic equalities (postulates of invariance of the original transformation). According to Marx, in the secondary conversion, we must ensure that the sum of prices equals the sum of values concerning the composition of the final social product. In doing so, we must ensure the invariance of real wages by breaking the equality between the sum of profits and the sum of surplus values of all the different branches of production. Bortkiewicz, "correcting" Marx, left only the postulate of primary transformation - the sum of profits of all the various production sectors must be equal to the sum of surplus value. The second postulate, Bortkiewicz discarded altogether, understanding by the social product the gross, not the final social product:

...Total price could coincide with total value. This would occur if the organic composition of the capital employed in the production of the monetary good, e.g. gold, bore a certain relation - which need not be discussed here - to the organic composition of all other capital. ${ }^{9}$ Nowhere in Marx, however, is there any mention of such a qualification. Without paying the slightest regard to the conditions of production of the good serving to measure values and prices, Marx simply asserts in general terms that total price equals total value. This assertion is not only unproven, it is false. (Bortkiewicz [1907] 1952, 11).

\footnotetext{
${ }^{9}$ Paul Sweezy discussed this case in his monograph The Theory of Capitalist Development. He wrote, "Only in the special case where the organic composition of capital in the gold industry is exactly equal to the social average organic composition of capital is it true that total price and total value will be identical." (Sweezy 1942, 122).
} 
However, Bortkiewicz was deeply mistaken about Marx's equality between the total price and the total value. Marx established this equality for the goods, which makes up the final social product. The final social product is the sum of the value newly created in a year (in hours of simple working time or in units of money directly proportional to them). This sum must remain constant under any method of pricing. The macroeconomic equality arising from this axiom does not require any proof. Without this equality, we lose the logical relationship between the price system and the value system of commodity production. We turn our attention to Mohun's excellent paper (Mohun 2018). The author argues for the fundamental conservation principle of total value added when transforming values into production prices. But to recognize the features of commodity labour-power, noted by the author, he would have to focus on the indirect and direct modification of the value of labour-power.

We can untangle the tangle of problems introduced by Tugan-Baranovsky and Bortkiewicz into Marx's theory of transformation. To this aim, we turn our attention to the result of Bortkiewicz's solution (see Table 1.3) and compare it so of the solution got by the secondary (equilibrium) transformation method described by Marx (see Table 5). As we can see, these results have the same rates of profit and rates of surplus value. Since these quantities are relative quantities, there is a linear relationship between the absolute quantities $c^{\prime}, v, p^{\prime}$ and respectively $c^{\prime \prime}, v^{\prime \prime}, p^{\prime \prime}$. Indeed, if we multiply all the absolute values of Table 5 by the index $q_{B}=1.04$, we get the corresponding absolute values of Table 1.3. This means that after the secondary transformation (see Table 5) and the Bortkiewicz solution (see Table 1.3) we got a similar system of the relative prices of production. ${ }^{10}$

We can solve the secondary transformation problem not only by using successive iterative calculations but also by applying the following system of simultaneous equations:

$$
\left.\begin{array}{l}
w_{1} k_{1}^{\prime \prime}=c_{1} k_{1}^{\prime \prime}+v_{1} k_{2}^{\prime \prime}+r^{\prime \prime}\left(c_{1} k_{1}^{\prime \prime}+v_{1} k_{2}^{\prime \prime}\right) \\
w_{2} k_{2}^{\prime \prime}=c_{2} k_{1}^{\prime \prime}+v_{2} k_{2}^{\prime \prime}+r^{\prime \prime}\left(c_{2} k_{1}^{\prime \prime}+v_{2} k_{2}^{\prime \prime}\right) \\
w_{3} k_{3}^{\prime \prime}=c_{3} k_{1}^{\prime \prime}+v_{3} k_{2}^{\prime \prime}+r^{\prime \prime}\left(c_{3} k_{1}^{\prime \prime}+v_{3} k_{2}^{\prime \prime}\right) \\
w_{2} k_{2}^{\prime \prime}+w_{3} k_{3}^{\prime \prime}=w_{2}+w_{3}
\end{array}\right\} .
$$

In system (8), the known quantities are $w_{i}, c_{i}, v_{i}$, and the unknowns are $k_{i}^{\prime \prime}$ and $r^{\prime \prime}$. When solving (8), we took the known quantities $\omega_{i}, c_{i}, v_{i}$ from Table 4.1 or 1.1 rather than the original solution from Table 4.2. ${ }^{11}$ In this case, we can also use Wolfram Mathematica and get the following estimates of the unknowns of a system (8):

$k_{1}^{\prime \prime}=1.2307692307692306 ; k_{2}^{\prime \prime}=1.0256410256410258 ; k_{3}^{\prime \prime}=0.9615384615384615$ and $r^{\prime \prime}=0.25$.

With these quantities $k_{i}^{\prime \prime}$ and $r^{\prime \prime}$, we get a solution that matches the absolute data in Table 5 . Therefore, we can determine the parameters $k_{i}^{\prime \prime}$ by comparing the quantities $\omega_{i}^{\prime \prime}$ in Table 5 with

${ }^{10}$ If we multiply all the absolute values in Table 5 by the index $q=0.91$, then get the result of the solution by the Winternitz method (see Winternitz, 1948). Here, the invariant quantity is the gross social product: $(\Sigma c+\Sigma v+\Sigma s)=875$. If we multiply the absolute data in Table 5 by $q B=0.975$, then we get the solution of Samuelson (1971) or Nguyen (1982). In these authors, the invariant quantity is $\Sigma v=300$.

${ }^{11}$ If we use $w_{i}^{\prime}, c_{i}^{\prime}, v_{i}$ from Table 3.3 or 4.2 , then we obtain quantities $r^{\prime \prime}=25.94 \% ; \omega_{1}^{\prime \prime}=465.568 ; \omega_{2}^{\prime \prime}=305.859$ and $\omega_{3}^{\prime \prime}=194.141$. These quantities deviate from the exact quantities (see Table 5) by $0.94 \% ; 0.15 \% ; 0.74 \%$ and $1.16 \%$ respectively. The deviations result from the fact that we use known data $w_{i}^{\prime}, c_{i}^{\prime}, v_{i}$ from Table 3.3 or 4.2. These data are not equilibrium data. 
the corresponding data $w_{i}$ in Table 4.1 or 1.1 . That means that we have verified the iterated method of the secondary transformation with Wolfram Mathematica.

We have also developed formulas for the secondary transformation of the data in Table 4.1 or 1.1 based on the Winternitz approach. With this approach, since the rates of profit should be equal in branches I and II, we can write:

$$
1+r^{\prime \prime}=\frac{w_{1} k_{1}^{\prime \prime}}{c_{1} k_{1}^{\prime \prime}+v_{1} k_{2}^{\prime \prime}}=\frac{w_{2} k_{2}^{\prime \prime}}{c_{2} k_{1}^{\prime \prime}+v_{2} k_{2}^{\prime \prime}}=R .
$$

Here, $r^{\prime \prime}$ is the general rate of profit that we get after the secondary transformation. From (9), we get the second-degree equation for $m=k_{1}^{\prime \prime} / k_{2}^{\prime \prime}$ :

$$
m=\frac{w_{2} c_{1}-w_{1} v_{2}+\sqrt{\left(w_{2} c_{1}-w_{1} v_{2}\right)^{2}+4 w_{1} w_{2} v_{1} c_{2}}}{2 w_{1} c_{2}}=1.2 .
$$

We then determine at the same time as $m$ the general rate of profit $r^{\prime \prime}$ and the price index $k_{2}^{\prime \prime}$ :

$$
\begin{gathered}
r^{\prime \prime}=\frac{w_{1} m}{c_{1} m+v_{1}}-1=0.25 . \\
k_{2}^{\prime \prime}=\frac{k_{1}^{\prime \prime}}{m} .
\end{gathered}
$$

In the system (8), we have:

$$
w_{2} k_{2}^{\prime \prime}+w_{3} k_{3}^{\prime \prime}=w_{2}+w_{3} .
$$

We then take equation $w_{3} k_{3}^{\prime \prime}=c_{3} k_{1}^{\prime \prime}+v_{3} k_{2}^{\prime \prime}+r^{\prime \prime}\left(c_{3} k_{1}^{\prime \prime}+v_{3} k_{2}^{\prime \prime}\right)$ from (8) and substitute it in (13):

$$
w_{2} k_{2}^{\prime \prime}+\left(c_{3} k_{1}^{\prime \prime}+v_{3} k_{2}^{\prime \prime}\right)\left(r^{\prime \prime}+1\right)=w_{2}+w_{3} \text {. }
$$

We previously defined we get: $k_{2}^{\prime \prime}$ and $r^{\prime \prime}+1=\frac{w_{1} m}{c_{1} m+v_{1}}=R$. If we substitute $k_{2}^{\prime \prime}$ and $R$ in (14), we get:

$$
\begin{aligned}
& w_{2} k_{2}^{\prime \prime}+\left(c_{3} k_{2}^{\prime \prime}+v_{3} k_{2}^{\prime \prime}\right)(\hat{r}+1)=w_{2}+w_{3} ; \\
& w_{2} \frac{k_{1}^{\prime \prime}}{m}+c_{3} k_{1}^{\prime \prime} R+v_{3} \frac{k_{1}^{\prime \prime}}{m} R=w_{2}+w_{3} ; \\
& w_{2} k_{1}^{\prime \prime}+c_{3} k_{1}^{\prime \prime} R m+v_{3} k_{1}^{\prime \prime} R=\left(w_{2}+w_{3}\right) m ; \\
& w_{2} k_{1}^{\prime \prime}+c_{3} k_{1}^{\prime \prime} R m+v_{3} k_{1}^{\prime \prime} R=\left(w_{2}+w_{3}\right) m ; \\
& k_{1}^{\prime \prime}=\frac{\left(w_{2}+w_{3}\right) m}{w_{2}+R\left(c_{3} m+v_{3}\right)}=\frac{\left(w_{2}+w_{3}\right) m}{w_{2}+\left(r^{\prime \prime}+1\right)\left(c_{3} m+v_{3}\right)} .
\end{aligned}
$$

So we have determined the indices $k_{1}^{\prime \prime}$ and $k_{2}^{\prime \prime}$. Next, we can determine the index $k_{3}^{\prime \prime}$. To do this, we substitute $k_{2}^{\prime \prime}$ into equation (13) and get:

$$
k_{3}^{\prime \prime}=\frac{\left(w_{2}+w_{3}\right)-w_{2} k_{2}^{\prime \prime}}{w_{3}} .
$$

We can also determine the index $k_{3}^{\prime \prime}$ by the algebraic transformation of the third equation of the system (8). 


\section{Developing a method of inverse transformation of prices into values}

Samuelson stated in his paper, that his attempts to the inverse transformation of production prices into values failed. He argued that after the inverse transformation "we ... can say in a dozen repetitive ways that... total of profit is not allocated by the value system according to where it was 'really produced'..." (Samuelson 1971, 417). Unfortunately, Samuelson did not give a single numerical example of the inverse transformation of production prices into value. Nor have such examples from Morishima and Seton, who, after Tugan-Baranowsky (1905), were among the first to consider the inverse transformation method (see Morishima and Seton 1961).

I tried to reconstruct Samuelson's train of thought and ended up with the following system of equations for the inverse transformation of Bortkiewicz's production prices into Marx's values:

$$
\left.\begin{array}{l}
x^{\prime} c_{1}^{\prime}+y^{\prime} v_{1}^{\prime}\left(1+m_{v}\right)=x^{\prime} w_{1}^{\prime} \\
x^{\prime} c_{2}^{\prime}+y^{\prime} v_{2}^{\prime}\left(1+m_{v}\right)=y^{\prime} w_{2}^{\prime} \\
x^{\prime} c_{3}^{\prime}+y^{\prime} v_{3}^{\prime}\left(1+m_{v}\right)=z^{\prime} w_{3}^{\prime}
\end{array}\right\} .
$$

Here $x^{\prime}, y^{\prime}$ and $z^{\prime}$ is the price change indices for constant capital, wage goods and luxury goods, respectively; $m_{v}$ is the visible rate of surplus value at equilibrium prices of production. In system (17), we used the Morishima-Seton $\Sigma \phi_{i}=\Sigma f_{i}$ or $\Sigma(v+\sigma)=\Sigma(v+s)$ assumption, reflecting their interpretation of the Marxist postulate that "total price equals total value" for the elements of the final social product $\phi_{i}$ and $f_{i}$ (see Morishima and Seton 1961, 210).

We will take, as in Bortkiewicz's solution, $z^{\prime}=1 .{ }^{12}$ Then we can determine the indices $x^{\prime}$ and $y^{\prime}$ by the following formulas:

$$
\begin{aligned}
x^{\prime} & =\frac{-w_{3}^{\prime} v_{1}^{\prime}}{\left(c_{1}^{\prime} v_{3}^{\prime}-w_{1}^{\prime} v_{3}^{\prime}-c_{3}^{\prime} v_{1}^{\prime}\right)} ; \\
y^{\prime} & =\frac{w_{3}^{\prime}-x^{\prime} c_{3}^{\prime}}{v_{3}^{\prime}\left(1+m_{v}\right)} .
\end{aligned}
$$

We obtained because of the solution of system (17), by substituting into it $c_{i}^{\prime}, v_{i}^{\prime}, w_{i}^{\prime}$ and $m_{v}=0.625$ from Table 1.3 , the following index magnitudes: $x^{\prime}=0.78125$ and $y^{\prime}=0.961538461538462$. We then determine $\tilde{m}_{1}=x^{\prime} w_{1}^{\prime}-\left(x^{\prime} c_{1}^{\prime}+y^{\prime} v_{1}^{\prime}\right)=57.692$ and the values of variable capital $\tilde{v}_{i}=y^{\prime} v_{i}^{\prime}$ and surplus value $\tilde{m}_{i}=\tilde{v}_{i} m_{v}$, where $m_{v}=62.5 \%$.

In Table 6, we present the outcomes of the inverse transformation carried out according to the assumed method Samuelson may have applied.

We compare Table 6 with Table 1.1 and see that we have accurately determined the value prices of the aggregates $w_{1}, w_{2}, w_{3}, c_{1}, c_{2}$, and $c_{3}$. However, as Samuelson wrote, we do not allocate the total profit by the value system according to where it was actually produced. For example, after the inverse transformation, the surplus value in the first branch is 57.692, when, in fact, it should be 60 (see Table 1.1). After the "inverse transformation," the magnitude of the newly created value $\Sigma v_{i}^{\prime}+\Sigma p_{i}=307.692+192.308=500$ coincides with the value of the final product $w_{2}+w_{3}=300+200=500$. However, the total value of variable capital does not coincide with

\footnotetext{
${ }^{12}$ We accept $z^{\prime}=1$ and ignore the second Morishima-Seton assumption $\left(v_{i}=v_{i}\right)$. This assumption specifies the equality of real wages in the systems of values and prices.
} 
the value of the product of the second branch, i.e. $\Sigma v_{i} \neq w_{2}$, and the sum of the surplus values does not coincide with the value of the product of the third branch, i.e. $\Sigma m_{i} \neq w_{3}$.

Table 6 . The result of the inverse transformation of production prices into values using model (17)

\begin{tabular}{|c|c|c|c|c|c|c|}
\hline \multirow{2}{*}{ Branches } & $\begin{array}{c}\text { Constant } \\
\text { Capital }\end{array}$ & $\begin{array}{c}\text { Variable } \\
\text { Capital }\end{array}$ & $\begin{array}{c}\text { Surplus } \\
\text { Value }\end{array}$ & Value & $\begin{array}{c}\text { General Rate of } \\
\text { Surplus Value }\end{array}$ & Rate of Profit \\
\hline$c_{i}$ & $\tilde{v}_{i}$ & $\tilde{m}_{i}$ & $w_{i}=c_{i}+\tilde{v}_{i}+\tilde{m}_{i}$ & $m_{v}$ & $\tilde{r}_{i}=\tilde{m}_{i} /\left(c_{i}+\tilde{v}_{i}\right)$ \\
\hline I & 225 & 92,308 & 57,692 & 375 & $62,5 \%$ & $18,182 \%$ \\
\hline II & 100 & 123,077 & 76,923 & 300 & $62,5 \%$ & $34,483 \%$ \\
\hline III & 50 & 92,308 & 57,692 & 200 & $62,5 \%$ & $40,541 \%$ \\
\hline Total & 375 & 307,692 & 192,308 & 875 & $62,5 \%$ & $28,169 \%$ \\
\hline
\end{tabular}

We believe that the way of transformation considered is probably one of a dozen ways of Samuelson. We could follow Samuelson in stating that the problem was unsolvable.

However, there is a way out of the impasse here. We can adjust the "way of Samuelson" and get the correct outcome of the inverse transformation of prices into values. To do this, we must change the magnitude of the price index $y^{\prime}$ so that inequality $\Sigma v_{i} \neq w_{2}$ turns into equality $k \Sigma v_{i}=w_{2}$.

We determine the amount of the coefficient $k$ by formula $k=w_{2} / \Sigma v_{i}$. Using the data in Table 6 , we determine $k=307.692 / 300=1.025641027$. Then we calculate the adjusted cost of variable capital $v_{i}=\tilde{v}_{i} / k$ and the surplus value $m_{i}=\left(w_{i}-c_{i}\right)-\tilde{v}_{i} / k$. The results coincide with the data in Table 1.1.13

There is an alternative method to inverse the transformation, based on the "way of Samuelson". From the material in Table 6, we can determine the real general rate of surplus value $m^{\prime}=w_{3} / w_{2}=200 / 300=2 / 3=66.667 \%$. We then distribute the magnitudes of the value-added $\left(\tilde{v}_{i}+\tilde{m}_{i}\right)$ into components $v_{i}$ and $m_{i}$, guided by the proportion $v_{i}: m_{i}=3: 2$.

Many researchers point out that the problem of inverse transformation still needs to be addressed (Ramos-Martínez and Herrera 1995; Foley 2011; Cogliano 2012; Sandemose 2016, Desai 2019). According to Lopez (2019), the search for an inverse transformation method has been successful, and Pasinetti made the best presentation of the results in his book Lectures on Production Theory (1977). Pasinetti explains the inverse transformation algorithm and that it is possible. However, Pasinetti's solution concerns relative prices, not absolute prices. It does not allow us to refute Samuelson's (1971) “eraser algorithm". We must discover the actual relationship between labour and capital. Therefore, we must perform the inverse transformation of production prices into absolute value prices. On this point, Desai wrote, "The price domain was the reduced form while the value domain was the structural form. You had to work backwards from the price domain to the value domain in order to make exploitation visible." (Desai 2019, 60).

I have developed a method for inverse transformation of production prices into values of the three-sector Tugan-Baranovsky-Bortkiewicz model (Kalyuzhnyi 2014). To transform Bortkiewicz's equilibrium prices of production (see Table 1.3) into Marx's values (see Table

${ }^{13}$ I used a similar approach in developing the inverse transformation method for Marx's five-sphere model (Kalyuzhnyi 2021). 
1.1), we must solve the following system of equations:

$$
\left.\begin{array}{l}
c_{1}^{\prime} J_{c}+v_{1}^{\prime} J_{v}+v_{1}^{\prime} J_{v} m^{\prime}=w_{1}^{\prime} J_{c} \\
c_{2}^{\prime} J_{c}+v_{2}^{\prime} J_{v}+v_{2}^{\prime} J_{v} m^{\prime}=w_{2}^{\prime} J_{v} \\
c_{3}^{\prime} J_{c}+v_{3}^{\prime} J_{v}+v_{3}^{\prime} J_{v} m^{\prime}=w_{3}^{\prime}
\end{array}\right\} .
$$

Where $m^{\prime}$ is the actual general rate of surplus-value, determined by the formula $m^{\prime}=\frac{w_{3}}{J_{v} \Sigma v_{i}^{\prime}}$; $J_{c}$ is the multiplier, which translates the price of production of constant capital into value; $J_{v}$ is the multiplier, which translates the production price of variable capital into value.

Given that $J_{v} m^{\prime}=\frac{w_{3}}{\Sigma v_{i}^{\prime}}=M$, we simplify the system of equations (20):

$$
\left.\begin{array}{l}
c_{1}^{\prime} J_{c}+v_{1}^{\prime} J_{v}+v_{1}^{\prime} M=w_{1}^{\prime} J_{c} \\
c_{2}^{\prime} J_{c}+v_{2}^{\prime} J_{v}+v_{2}^{\prime} M=w_{2}^{\prime} J_{v} \\
c_{3}^{\prime} J_{c}+v_{3}^{\prime} J_{v}+v_{3}^{\prime} M=w_{3}^{\prime}
\end{array}\right\} .
$$

Using the first and third equations of the system (21), we get formulas to determine the unknowns $J_{c}$ and $J_{v}$ :

$$
\begin{aligned}
& J_{v}=\left[\left(c_{1}^{\prime}-w_{1}^{\prime}\right)\left(w_{3}^{\prime}-v_{3}^{\prime} M\right)+c_{3}^{\prime} v_{1}^{\prime} M\right] /\left[\left(c_{1}^{\prime}-w_{1}^{\prime}\right) v_{3}^{\prime}-v_{1}^{\prime} c_{3}^{\prime}\right] . \\
& J_{c}=-v_{1}^{\prime} w_{3}^{\prime \prime} /\left[\left(c_{1}^{\prime}-w_{1}^{\prime}\right) v_{3}^{\prime}-v_{1}^{\prime} c_{3}^{\prime}\right] .
\end{aligned}
$$

By substituting the known numerical model parameters from Table 1.3 into equations (22) and (23) and solving it about the unknowns, we get $J_{v}=0.9375$ and $J_{c}=0.78125$. After that, we calculate the real general rate of surplus value: $m^{\prime}=M / J_{v}=0.625 / 0.9375=0.6667$ or $66.667 \%$. Using the known magnitudes of $J_{c}, J_{v}$ and $m^{\prime}$, we transform the model in equilibrium production prices (see Table 1.3) into the initial value model (see Table 1.1).

Above, we have performed the inverse transformation of the secondary prices of production got by Bortkiewicz. We apply the following formulas to determine the multipliers $J_{c}, J_{v}$ and the surplus-value rate $m^{\prime}$, with which we can carry out the inverse transformation of Marx's secondary prices of production (see Table 5) into the original values (see Table 1.1):

$$
\begin{aligned}
& J_{v}^{\prime}=J_{v} q_{B}=0.9375 \times 1.04=0.975 \\
& J_{c}^{\prime}=J_{c} q_{B}=0.78125 \times 1.04=0.8125 \\
& m^{\prime}=\omega_{3}^{\prime \prime} q_{B} / \omega_{2}^{\prime \prime} J_{v}^{\prime}=(192.308 \times 1.04) /(307.692 \times 0.975)=200 / 300=0.6667
\end{aligned}
$$

Thus, there is an unconditional intrinsic interrelationship between the branch value model and the same model in the secondary (equilibrium) production prices. We do not need any prior information about the real general rate of surplus value to transform the prices of production into their values inversely. We can transform the prices of production into values and, in doing so, determine the actual total rate of surplus value. That means that the system of production prices determines the level of the total rate of real surplus product.

Therefore, the general rate of surplus value assumed by Marx as a theoretical simplification is not only a prerequisite of the system of production prices established because of the mutual competition of capitals, but also a practical consequence of the existence of this system 
of prices. The production price system contains information about the actual exploitation of the labour-power, but if we define the subsystem of goods that make up the basket of real wages. This means that we can determine, with a measure of precision, the sectoral deviations of prices from value. To do this, we must, based on the law of large numbers, estimate the error in calculating the general rate of surplus value in the national economy. As a result, we will know the measure of the discrepancy between the market prices of production and the value of the goods in question.

The production price system contains information about the actual exploitation of the labourpower, but if we define the subsystem of goods that make up the basket of real wages.

On this point, P. Fireman $(1863-1962)^{14}$ concluded

that some goods must sell above, others to the same extent below their value and that only the commodities of industries with a particular ratio c:v of average size receive a price that corresponds to their true value. Is this discrepancy between individual prices and their corresponding values a refutation of the principle of value? It is not at all. For because the prices of some goods rise above value to the same extent as the prices of other goods fall below value, the total sum of prices remains equal to the total sum of values. ${ }^{15} \mathrm{~A}$ mismatch can be seen as a disturbance in the exchange of goods because of the inherent values of the goods, as a disturbance caused by competition. In the exact sciences, however, a disturbance that can be accurately calculated is never regarded as a disproof of the law. (Fireman 1892, 808).

Finally, I draw attention to another peculiarity of the considered methods of transforming values into prices and prices into values. Anwar Shaikh recently published the following remarkable thought:

A common neo-Ricardian claim is that Marx's "erroneous transformation algorithm" arose because he "did not have the method of simultaneous equations at his disposal" (Gehrke and Kurz 2006, p. 214). Yet in Marx's presentation of his algorithm, he is careful to state that it is a first step because any deviations of prices from values implies that costs previously expressed in labour value terms must be further adjusted to reflect the new prices. (Shaikh 2021, 368)

In my opinion, if we get a solution to a system of equations using the sequential iteration method, then applying the corresponding system of simultaneous equations for the same purpose can serve as a test of the iterative process. We have tested two iterative methods for solving the transformation problem: 1) the initial transformation method and 2) the secondary transformation method. These methods require knowledge of only four arithmetic operations. Marx could well apply them to perform several iterative steps using his postulates of invariance.

We support this hypothesis by Marx's assertion:

... A general nominal increase in the rate of profit and the average profit above the limit provided by the ratio of the actual surplus value to the total invested capital is not, in effect,

${ }^{14}$ Peter Fireman was born in Lipovetz, Russian Empire (nowadays Ukraine), Apr. 4, 1863, son of Ephim and Bella (Gorchovski) Fireman. He died in Hunterdon County, N.J., Apr. 27, 1962 - buried Ewing Cemetery, Trenton, N.J. (see Alcouffe 2021).

15 "We begin," wrote Fireman, "with an analysis of the realized price of the commodity as the final result of the process of production and exchange... Since the quantity representing the value of the means of production consumed appears in the produced product in an unchanged form, we can dispense with it as a constant value. If we exclude it, we are left with the components of wages and profits." (Fireman 1892, 799). It means that Fireman referred to the equality between the sum of prices and the sum of values for the goods that make up the final social product. Fireman's thought finds confirmation in Volume II of Capital, where Marx wrote, “... From the point of view of society the fourth element of Adam Smith, the constant capital value, disappears." (Marx, [1885] 1997, 383). 
possible without causing an increase in wages, and also an increase in the prices of commodities forming the constant capital. (Marx [1894] 1998, 178-9)

We have shown that the secondary transformation raises the price of constant capital over its value by $23.1 \%$ and variable capital by $2.6 \%$. The general rate of profit decreases to $25 \%$. Thus, Marx correctly foresaw changes in the prices of constant and variable capital, as well as the rate of profit. Without doing the proper calculations, it was not so easy for Marx to do this.

So, how can we now prove that profit arises from the surplus value generated by the workers and from no other source? Of course, the best minds of the vulgar political economy look solely at the system of production prices. They may argue that capitalists invest capital to make profits and derive those profits equally from the fixed and circulating components of the applied capital. However, we can look at the output of annual social production as the net social product. From the physical point of view, this is the final social product, which comprises consumption goods for the workers and the capitalists. ${ }^{16}$ From the value point of view, we may regard the net social product as the sum of the annual labour inputs of all the workers in the country, expressed abstractly in hours of simple labour. Production prices distribute this aggregate value between workers and capitalists in different ways. Workers receive wages in proportion to their expenditure of simple labour-power, while capitalists receive profits in proportion to their functioning productively applied capital. The result is a snag. As the prices of the production of goods deviate from their values, aggregate profit diverges from aggregate surplus value. As a result, aggregate wages do not coincide with the aggregate value of paid labour. That means that under conditions of production prices, we cannot determine the actual degree of the exploitation of labour-power. Nor can we claim that profit arises from the surplus value generated by workers.

However, we can solve this problem by converting the production prices of goods into their value prices, directly proportional to the costs of socially necessary labour time. We used the Tugan-Baranovsky-Bortkiewicz model and developed a method for transforming prices back into values. We have also shown that the money structure of the net social product changes after the inverse transformation. At production prices, it is $\omega_{2}^{\prime \prime}+\omega_{3}^{\prime \prime}=307.692+$ $192.308=500$, and at value prices $w_{2}+w_{3}=300+200=500$. Only at value-prices, in all industries, net value added and surplus value are directly proportional to the values of paid labour-power: $\left(v_{i}+m_{i}\right) / v_{i}=1 \frac{2}{3}$ and $m_{i} / v_{i}=2 / 3$ (see Table 1.1). We can regard the two systems, value and price, as the same physical system comprising the same commodities. Therefore, we can express all goods at production prices at constant prices equal to the value prices. As a result, we see that the sum of the objects of consumption for the capitalists at constant prices equals total surplus value. That means that the income (profit) of the capitalists coincides with the aggregate surplus value.

Representatives of the mainstream cannot deny this. After all, they identify the effects of inflation (or deflation) by expressing Gross (or better, Net) Domestic Product at constant prices of the previous year. Here, we identify the equality between the sum of profit and the sum of surplus value by an analogous method. That means that profits come from surplus value generated by workers and from no other source. That was what needed to be proved.

\footnotetext{
${ }^{16}$ Under reproduction on an extended scale, capitalists consume part of their income to accumulate constant and variable capital.
} 


\section{The standard solution and a critique of the thesis of the redundancy of the labour theory of value}

It is well known that the use of the Sraffa model to solve the transformation problem led to a standard solution to this problem. The standard solution emerged through the efforts of Samuelson (1971), Steedman (1977), Pasinetti (1977) and others. The standard solution was the source of the thesis of the redundancy of the labour theory of value (see Lopez 2021, 93).

We are forced to refute this thesis as erroneous. For this purpose, we will use a paper by Nguyen (1982), in which he criticized Samuelson's paper (1971) and relied on Bortkiewicz's numerical example, presenting a standard solution by matrix algebra.

Nguyen begins by calculating a matrix of inter-industry coefficients that reflects a technology for a given hypothetical economy. We can write such a matrix for a three-industry Bortkiewicz economy as:

$$
A=\left[\begin{array}{lll}
a_{11} & a_{12} & a_{13} \\
a_{21} & a_{22} & a_{23} \\
a_{31} & a_{32} & a_{33}
\end{array}\right]=\left[\begin{array}{ccc}
225 / 375 & 0 & 0 \\
100 / 375 & 0 & 0 \\
50 / 375 & 0 & 0
\end{array}\right]=\left[\begin{array}{ccc}
9 / 15 & 0 & 0 \\
4 / 15 & 0 & 0 \\
2 / 15 & 0 & 0
\end{array}\right]
$$

where $A(i=1,2,3$ and $j=1,2,3)$ are the units of good $\mathrm{j}$ required to produce one unit of good $i$. For example, $a_{21}$ shows that to produce one unit of commodity 2 (consumption goods for workers), we need $a_{21}=4 / 15$ units of commodity 1 (means of production).

To reflect the labour requirements in the production of all three goods, we define a matrix $B$ of the form:

$$
A=\left[\begin{array}{lll}
a_{11} & a_{12} & a_{13} \\
a_{21} & a_{22} & a_{23} \\
a_{31} & a_{32} & a_{33}
\end{array}\right]=\left[\begin{array}{ccc}
225 / 375 & 0 & 0 \\
100 / 375 & 0 & 0 \\
50 / 375 & 0 & 0
\end{array}\right]=\left[\begin{array}{ccc}
9 / 15 & 0 & 0 \\
4 / 15 & 0 & 0 \\
2 / 15 & 0 & 0
\end{array}\right]
$$

To calculate matrices $A$ and $B$, we use the data in Table 1.1 or 1.3 . We finally get the following:

$\begin{array}{ll}a_{11}=c_{1} / p_{1}=9 / 15 & b_{12}=v_{1} / p_{2}=3 / 10 ; \\ a_{21}=c_{2} / p_{1}=4 / 15 ; & b_{22}=v_{2} / p_{2}=4 / 10 ; \\ a_{31}=c_{3} / p_{1}=2 / 15 ; & b_{32}=v_{3} / p_{2}=3 / 10 .\end{array}$

Nguyen proposes to use the data from matrices $A$ and $B$ to determine the values of $p$ and the prices of production $P$. He summarises the Marxist model of value prices with the following formula:

$$
[A+(1+s) B] p=p
$$

where $s$ is the general rate of surplus value.

He presents the Marxist model of the price of production with the formula:

$$
[(1+r)[A+B] P=P,
$$

where $r$ is the general rate of profit.

From models (30) and (31) we have

$$
\begin{aligned}
& {[A+(1+s) B-I] p=0,} \\
& \{(1+r)[A+B]-I\} P=0,
\end{aligned}
$$

where $I$ is the identity matrix of order 3 . 
Then we can use the well-known transformations of formulas (32) and (33) to determine, first, the surplus value rate $s$ and the relative values $p_{i} / p_{n}$, and second, the profit rate $r$ and the relative prices of production $P_{i} / P_{n}$.

We can obtain the eigenvectors $\left\{p_{1}, p_{2}, p_{3}\right\}$ if we normalise the system of equations (30) by taking $p_{2}=300$ from the Bortkiewicz model. We end up with $s=2 / 3$; relative values $p_{1} / p_{2}=1.25 ; p_{2} / p_{2}=1 ; p_{3} / p_{2}=2 / 3$ or absolute values $p_{1}=375 ; p_{2}=300 ; p_{3}=200$. If we normalize the system (31) at $P_{2}=320$, taking this figure from the Bortkiewicz model in production prices, we get $r=0.25$; relative prices $P_{1} / P_{2}=1.5 ; P_{2} / P_{2}=1 ; P_{3} / P_{2}=0.625$ or absolute prices $P_{1}=480 ; P_{2}=320 ; P_{3}=200$.

Note that we took $P_{2}=320$, while Samuelson and Nguyen took $P_{2}=300$. Therefore, we fulfil Bortkiewicz's postulate and one of Marx's postulates $P_{2}=p_{2}$. We confirm Nguyen's conclusion that although systems (32) and (33) differ, they do not differ arbitrarily. The two matrices $A$ and $B$ appearing in (32) and (33) are identical; the surplus-value rate s and the profit rate $r$ are got directly from $A$ and $B$. Thus, we see that the two models (the value model and the price model) are related to each other through the important common technological matrices $A$ and $B$. We therefore also do not believe that the Marxian transformation algorithm can be satisfactorily completed by a simple 'erasure' procedure, as Professor Samuelson argued.

We can show that relative prices use relative values as determinants. To do this, let us write the relative values model in the form:

$$
\left(\begin{array}{l}
p_{1}=a_{11} p_{1}+b_{12} \\
p_{2}=a_{21} p_{1}+b_{22} \\
p_{3}=a_{11} p_{1}+b_{32}
\end{array}\right): p_{2} \rightarrow\left(\begin{array}{l}
p_{1}=(9 / 15) p_{1}+0.3 \\
p_{2}=(4 / 15) p_{1}+0.4 \\
p_{3}=(2 / 15) p_{1}+0.3
\end{array}\right): p_{2} \rightarrow \begin{gathered}
p_{1} / p_{2}=1.25 \\
p_{2} / p_{2}=1 \\
p_{3} / p_{2}=2 / 3
\end{gathered}
$$

Where matrices $A$ and $B$ are defined from the Bortkiewicz model in production prices.

If we assume $p_{2}=300$, then from (34) we obtain $p_{1}=375 ; p_{3}=200$. It is easy to see that by using the model data in production prices to calculate matrices $A$ and $B$, we determine the values of $\left\{p_{1}, p_{2}, p_{3}\right\}$ and the total rate of surplus value $s=2 / 3$. This means that we carry out the inverse transformation of production prices into values in the framework of the standard solution.

Further analysis shows that we can represent vector $B$ as follows:

$$
\left.\begin{array}{l}
b_{12}=p_{1}\left(1-a_{11}\right) \\
b_{22}=p_{2}-a_{21} p_{1} \\
b_{32}=p_{3}-a_{11} p_{1}
\end{array}\right\}
$$

Since we use vector B in determining production prices (see formula (31)), we do not doubt that $\left\{p_{1}, p_{2}, p_{3}\right\}$ values underlie the determination of production prices, but implicitly. Steedman argued that "the determination of the profit rate (and prices of production) is thus logically prior to the determination of the values of commodities. Clearly, then, values cannot determine the rate of profit (or the prices of production)." (Steedman 1977, 204). However, it is now clear that Marx was right when he wrote:

If one did not take the definition of value as the basis, the average profit, and therefore also the cost prices, would be purely imaginary and untenable. The equalisation of the surplus values in different trades does not affect the absolute size of this total surplus value; but merely alters its distribution in the different trades. The determination of this surplus value itself, however, only arises out of the determination of value by labour time. Without this, the 
average profit is the average of nothing, pure fancy. And it could then equally well be $1,000 \%$ or 10\%." (Marx 1989: 415-6).

If we did not take the value derived from the definition of value by working time as the basis for calculating absolute prices of production, the average profit contained therein would be an average of nothing, a pure fantasy. We would not understand what prices would be appropriate for the organisation of pricing under socialism.

\section{The practical importance of price transformation methods}

In what follows we will treat the two systems, - - in values and production prices, - as the same physical system of use values. The question immediately arises. Why do we need the value system (see Table 1.1) if capitalists seek to increase their profits, and under competition between capitals, the value of goods is transformed into prices of production (see Table 1.3)? The answer to this question involves the question of the limits of the capitalist use of machines, which Marx discussed in part in Volume I of Capital (see pp.400-405) and then in Volume III of Capital (see pp.285-288). Marx writes:

For a new method of production to represent a real increase in productivity, it must transfer a smaller additional portion of the value of fixed capital to each unit of the commodity in wear and tear than the portion of value deducted from it through the saving in living labour; in short, it must reduce the value of the commodity. ... This reduction of the total quantity of labour going into a commodity seems, accordingly, to be the essential criterion of increased productive power of labour, no matter under what social conditions production is carried on. Productivity of labour, indeed, would always be measured by this standard in a society, in which producers regulate their production according to a preconceived plan, or even under simple commodity production. But how does the matter stand under capitalist production? (Marx [1894] 1998, 260)

Marx answers this question after considering a numerical example in the following way:

"The law of the increased productive power of labour is not ... absolutely valid for capital. So far as capital is concerned, this productive power does not increase through a saving in living labour in general, but only through a saving in the paid portion of living labour, as compared to labour expended in the past, as we have already indicated in passing in Book I (Kap. XIII, 2, S. 409/398).” (Marx [1894] 1998, 261).

Marx assumed in his example that the composition of capital in production, in which the machine replaces the labour of the labourers, is equal to the average configuration of social capital $c: v$. Under this assumption, the price of production of the commodity coincides with value, and the capitalist's profit is equal to the surplus value produced. Marx then calculated the new value and the new price of production. In his example, the new value per unit of the commodity is reduced by $1 \mathrm{~s}$ and the new price is $22 \mathrm{~s}$, i.e. it remains unchanged. However, this way of comparing pricing models did not gain further traction.

We can now make a comprehensive price comparison using the same model of reproduction in value and in production prices. Beforehand, we will disclose two conjugate methods of estimating the productive power of labour, which Marx proposed. In the first case, Marx argued that the productive power of labour under value prices increases when a new method of producing a unit of the same commodity leads to a decrease in its individual value, i.e.:

$$
C_{1}+V_{1}(1+m)>C_{2}+V_{2}(1+m) \text { or } W_{1}>C_{2}+V_{2}(1+m),
$$


Where $C_{1}$ and $C_{2}$ are the cost of constant capital per unit of good in the base and new production period, respectively; $V_{1}$ and $V_{2}$ are the cost of variable capital per unit of good in the base and new production period, respectively; $W_{1}$ is the cost per unit of good in the base period; $m$ is the general rate of surplus value in the economy. In the second case, Marx argued as follows:

It is nonsense to talk of the greater or lesser productivity of two different branches of industry when merely comparing the values of their commodities. If, [in] 1800, the pound of cotton was $2 \mathrm{~s}$. and of yarn $4 \mathrm{~s}$., and if, in 1830 , the value of cotton was $2 \mathrm{~s}$. or $18 \mathrm{~d}$. and that of yarn $3 \mathrm{~s}$. or $1 \mathrm{~s} .8 \mathrm{~d}$. then one might compare the proportion in which the productivity in both branches had grown - but only because the rate of 1800 is taken as the starting-point. On the other hand, because the pound of cotton is $2 \mathrm{~s}$, and that of yarn is 3 , and hence the labour which produces the cotton is as great again as the [newly-added labour] of spinning, it would be absurd to say that the one is twice as productive as the other. Just as absurd as it would be to say that because canvas can be made more cheaply than the artist's painting on the canvas, the labour of the latter is less productive than that of the former. (Marx [1861-63] 1989, 341-2)

We write down this statement by Marx using the following inequality:

$$
\frac{W_{1}-C_{2}}{V_{2}}=(1+m) \text { or } \frac{W_{1}-C_{2}}{L_{2} v_{1}}=(1+m)
$$

Were $\left(W_{1}-C_{2}\right)=D_{2}$ is the net value added per unit of goods in the new period, in base period prices; $L_{2}$ is the input of live labour per unit of goods in the new period, in physical units (hours of simple labour); $v_{1}$ is the wage per unit of live simple labour in the base period.

As we can see, Marx measures the net value-added and the inputs of live labour in the corresponding prices of the base period. There is no doubt about this because we get the inequality characterizing the growth of the productive power of labour (37) from the elementary transformation of inequality (36). These inequalities are conjugate, i.e., noncontradictory. If one inequality shows an increase in the productive power of labour, then the second inequality will necessarily also show a similar increase. We now present Marx's example in Table 7. Here, we assume that all cotton is produced by hand and fully utilised as constant capital in yarn production. We also take up that the rate of surplus value in cotton and yarn production is the same and is $100 \%$.

The calculations show that, in cotton production, the level of the productive power of labour did not change and was 1800 and 1830: $(V+M) / V=2 / 1=2$. The index of the productive power of labour was $2 / 2=1$, showing no increase in this indicator. In yarn production, the level of productive power of labour in 1800 was $(V+M) / V=2 / 1=2$, and in 1830, it increased to $(V+M) / V=2 / 0.5=4$ or $4 / 2=2$.

Table 7. Marx starting data for measuring the productive power of labour in two different branches of production

\begin{tabular}{|c|c|c|c|c|c|c|c|c|c|c|}
\hline & \multicolumn{5}{|c|}{1800} & \multicolumn{5}{|c|}{1830} \\
\hline & $C$ & V & $M$ & $W=C+V+M$ & $D=V+M$ & $C$ & V & $M$ & $W=C+V+M$ & $D=V+M$ \\
\hline \multicolumn{11}{|c|}{ At current 1830 prices } \\
\hline Cotton & - & 1 & 1 & 2 & 2 & - & 1 & 1 & 2 & 2 \\
\hline Yarn & 2 & 1 & 1 & 4 & 2 & 2 & 0,5 & 0,5 & 3 & 1 \\
\hline \multicolumn{11}{|c|}{ At constant 1800 prices } \\
\hline Cotton & & & & & & - & 1 & 1 & 2 & 2 \\
\hline Yarn & & & & & & 2 & 0,5 & 1,5 & 4 & 2 \\
\hline
\end{tabular}


We now will use the data in Tables 1.1 and 1.3 and assume that the second industry introduces a new machine, which causes fixed capital to increase 1.3 times and variable capital to decrease 1.4 times, at constant base period prices (see Table 8).

A comparison of Tables 1.1 and 8.1 shows that the second branch implemented a machine at a value of 30 monetary units. This action entailed a 1.2-fold increase in the output of constant capital in the first branch (from 375 to 450 ). We find this index $X_{2}=1.2$ from the following equation:

$$
c_{1} X_{2}+\left(c_{2}+c_{2}^{m}\right)+c_{3}=w_{1} X_{2} \text { or } X_{2}=\frac{\left(c_{2}+c_{2}^{m}\right)+c_{3}}{\left(w_{1}-c_{1}\right)},
$$

Where $c_{1}, c_{2}, c_{3}$ is the branch constant capital values in the base period; $c_{2}^{m}$ is the value of the machine implemented in the new period; $w_{1}$ is the output value of the first branch in the base period.

Table 8. Hypothetical result of introducing a new machine when pricing at value and production prices

\begin{tabular}{|c|c|c|c|c|c|c|}
\hline \multicolumn{7}{|c|}{ 8.1. Model in Value Prices } \\
\hline \multirow[t]{2}{*}{ Branches } & $\begin{array}{c}\text { Constant } \\
\text { Capital }\end{array}$ & $\begin{array}{l}\text { Variable } \\
\text { Capital }\end{array}$ & $\begin{array}{l}\text { Surplus } \\
\text { Value }\end{array}$ & Value & $\begin{array}{c}\text { General Rate of } \\
\text { Surplus Value }\end{array}$ & Rate of Profit \\
\hline & $c_{i}$ & $v_{i}$ & $m_{i}$ & $w_{i}=c_{i}+v_{i}+m_{i}$ & $\sigma=m_{i} / v_{i}$ & $r_{i}=m_{i} /\left(c_{i}+v_{i}\right)$ \\
\hline I & 270 & 108 & 72 & 450 & $66.667 \%$ & $19.048 \%$ \\
\hline II & 130 & 85.714 & 84.286 & 300 & $98.333 \%$ & $39.073 \%$ \\
\hline III & 50 & 90 & 60 & 200 & $66.667 \%$ & $42.857 \%$ \\
\hline Total & 450 & 283.714 & 216.286 & 950.0 & $76.234 \%$ & $29.478 \%$ \\
\hline \multicolumn{7}{|c|}{ 8.2. Model in Prices of Production } \\
\hline \multirow[t]{2}{*}{ Branches } & $\begin{array}{l}\text { Constant } \\
\text { Capital }\end{array}$ & $\begin{array}{l}\text { Variable } \\
\text { Capital }\end{array}$ & Profit & $\begin{array}{l}\text { Prices of } \\
\text { Production }\end{array}$ & $\begin{array}{l}\text { Rate of Surplus } \\
\quad \text { Value }\end{array}$ & $\begin{array}{c}\text { General Rate of } \\
\text { Profit }\end{array}$ \\
\hline & $c_{i}^{\prime}$ & $v_{i}^{\prime}$ & $p_{i}$ & $w_{i}^{\prime}=c_{i}^{\prime}+v_{i}^{\prime}+p_{i}$ & $\sigma_{i}^{\prime}=\sigma p_{i} / v_{i}^{\prime}$ & $r_{i}=p_{i} /\left(c_{i}^{\prime}+v_{i}^{\prime}\right)$ \\
\hline I & 345.6 & 115.2 & 115.2 & 576 & $100 \%$ & $25 \%$ \\
\hline II & 166.4 & 91.429 & 62.171 & 320 & $68 \%$ & $24.113 \%$ \\
\hline III & 64 & 96 & 40 & 200 & $41.667 \%$ & $25 \%$ \\
\hline Total & 576 & 302.629 & 217.371 & 1096 & $71.828 \%$ & $24.740 \%$ \\
\hline
\end{tabular}

We will now use formula (37) and use the data in Tables 1.1 and 8.1 to calculate, for the second branch, the levels of labour productivity in the base period $t$ and the new period $t+1$ :

- base period $J_{t}=\frac{W_{2}^{t}-C_{2}^{t}}{V_{2}^{t}}=\frac{300-100}{120}=1$. (6);

- new period $J_{t+1} \frac{W_{2}^{t+1}-C_{2}^{t+1}}{V_{2}^{t+1}}=\frac{300-130}{85 .(714285)}=1.98(3)$.

Thus, when using value prices, the index of the productive power of labour $I_{I, m}$ is:

$$
I_{I, m}=\frac{J_{t+1}}{J_{t}}=\frac{1.98(3)}{1 .(6)}=1.19
$$

We now use the data in Tables 1.3 and 8.2 and determine the index of the productive power of labour $I_{I, r}$ at production prices. In this case, the second branch implements a new machine at the cost of 38 monetary units, which causes a reduction of 36.571 units of variable capital 
expenditure. This event entails a 1.2 - fold increase in the output of constant capital in the first branch (from 480 to 576 ).

We then use the known formulas and obtain the following results for calculating the levels of labour productivity in the base period $t$ and the new period $t+1$ :

- base period $J_{t}=\frac{W_{2}^{t}-C_{2}^{t}}{V_{2}^{t}}=\frac{320-128}{128}=1.5$;

- new period $J_{t+1} \frac{W_{2}^{t+1}-C_{2}^{t+1}}{V_{2}^{t+1}}=\frac{320-166.4}{91 .(428571)}=1.68$.

Thus, using production prices, the index of the productive power of labour $I_{I, r}$ is:

$$
I_{I, r}=\frac{J_{t+1}}{J_{t}}=\frac{1.68}{1.5}=1.12
$$

As we can see, Marx's index of the productive power of labour under production price conditions also shows the efficiency of the new machine. However, if we look at the change in the rate of profit in the second branch, we see it drop from $25 \%$ to $24.113 \%$. This means that the production price of the product of the second branch after implementing the new machine does not decrease but increases. I have shown (Kalyuzhnyi 2010, 16) that under production prices, the measurement of the productive power of labour can be made using an index which is conjugated with the criterion of profit rate increase:

$$
J_{2}^{t+1}=\frac{\left(W_{2}^{t}-C_{2}^{t+1}\right)-r K_{2}^{t+1}}{V^{t+1}}>1
$$

Here, $K_{2}^{t+1}$ is the applied capital of the second branch at period $t+1\left(K_{2}^{t+1}=C_{2}^{t+1}+V_{2}^{t+1}\right)$.

If we use the data in Tables 1.3 and 8.1, formula (30) gives us:

$$
J_{2}^{t+1}=\frac{\left(W_{2}^{t}-C_{2}^{t+1}\right)-r K_{2}^{t+1}}{V_{2}^{t+1}}=\frac{(320-166.4)-0.25(166.4+91 .(428571)}{91 .(428571)}=0.975
$$

Here, $J_{2}^{t+1}<1$, which shows a decrease in the work's effectiveness of the second branch because of introducing the new machine. However, if value prices and an appropriate criterion of efficiency were used, we would recognise that this machine is efficient because it markedly increases the productive power of labour. It is, therefore, no coincidence that Engels in Anti-Dühring (see Marx 1987, 294-5) and Marx in Capital suggested that, in a transitional period, production prices should be replaced by value prices directly proportional to the socially necessary labour input. For example, Marx wrote:

... After the abolition of the capitalist mode of production, but still retaining social production, the determination of value continues to prevail in the sense that the regulation of labour time and the distribution of social labour among the various production groups, ultimately the bookkeeping encompassing all this, become more essential than ever. (Marx [1894] 1998, 838).

\section{Conclusion}

We have found that Bortkiewicz's so-called "correction" of Marx's solution to the problem of transformation introduced several fundamental errors into the economic discussion of this issue, which economists repeat to this day, namely:

1. Bortkiewicz did not understand that Marx's tables in chapter 9 of volume III of Capital are about different and independent production spheres, and not about the mutually 
dependent branches that form the total social product. Bortkiewicz even tried to tweak Marx's table and achieve in it a balance of industries characteristic of the three-sector model (see Bortkiewicz [1907] 1952, 8-9).

2. Bortkiewicz did not see that Marx eliminated the double counting of profits and wages in the system of spheres of production. Therefore, Bortkiewicz understood the social product to mean the gross product, not the final product, as Marx did.

3. Bortkiewicz ignored the fact that Marx's process of transformation of values into prices of production comprises two stages. First, there is the formation of the average rate of profit in each separate sphere of production, comprising sector $\mathrm{A}$, which produces an intermediate product, and sector $\mathrm{B}$, which produces a final product. Then there is the alignment of the rates of profit into the general rate of profit in the particular spheres comprising sectors $\mathrm{B}$. These two stages are repeated until the final general rate of profit is established in all sectors A and B.

4. Bortkiewicz failed to notice that Marx, in Volume III of Capital, considers two approaches to transformation, differing in postulates of invariance. In the first case, Marx considers the original transformation of values into prices, relying on the equality of the sum of values and the sum of the prices of production of the final social product and the postulate of invariance of nominal wages. The consequence of these assumptions is the equality of the sum of profits and the sum of surplus values of all sectors of the economy $A$ and B. The original transformation results in a direct modification of the value of constant capital and an indirect modification of the value of variable capital. Indirect modification means that there is some change in real wages. However, with many goods produced in the economy, the law of large numbers leads to the restoration of the level of real wages.

In the second case, Marx addresses secondary transformation by relying on the equality between the sum of the values and the sum of the production prices of the final social product. He also uses the postulate of a change in nominal wages to a level that restores real wages. As a result, the value of the final social product does not change. There is only a redistribution of the sum of wages and the sum of profits. Eventually, the prices of production become equilibrium. However, the sum of profits is no longer equal to the sum of surplus values.

We can reach the macroeconomic symmetry between demand and supply of goods if we consider the actual quantity of goods and the operation of the law of large numbers. Thus, we see that the secondary prices of goods can be equilibrium without changing the value proportion between the sums of wages and profits.

5. Bortkiewicz misinterpreted Marx's main transformation table from chapter 9 of volume III of Capital as representing Marx's end solution to the problem of the average rate of profit. I am against this interpretation and consider this table, as do some other researchers, the first stage of further iterative calculations.

I have also established that we can decompose the three-sector model into two sub-systems. Either of them produces one commodity as the final product. It also reproduces the means of production used in it. I have shown that we can apply the changed model to iterative calculations of original and secondary transformation of values into production prices. The accuracy of iterative calculations is not inferior to the accuracy of calculations performed by solving a system of simultaneous equations.

I concluded Marx regarded equality between price and the value of the final social product as the fundamental transformational postulate of invariance. ${ }^{17}$ Marx fulfils this postulate in both

\footnotetext{
${ }^{17}$ This statement coincides with the formulation of the fundamental principle of conservation of total net value-added:
} "For any specification of prices, the total value created by labour in all value-creating production processes 
the initial and the secondary transformation of values into prices. As for Marx's second postulate - the sum of the profits of all the different spheres of production must be equal to the sum of surplus value - we have to fulfil this postulate only in the original transformation. In the secondary transformation, Marx ignores the equality between the sum of profit and the sum of surplus value. Thus, he does not show the source of the origin of profit, but he does not eliminate it. Apparently, Marx regarded the secondary transformation as a side issue for this reason.

The fundamental error of Bortkiewicz is that he performed the secondary transformation, but, unlike Marx, put forward as the central postulate of invariance of this transformation the equality between the sum of profit and the sum of surplus value. Not understanding Marx's theoretical constructions, Bortkiewicz threw overboard the invariance of the gross social product, although Marx was talking about the final social product. Bortkiewicz's mistakes played the role of the very flute of the Hamelin's piper, with the help of which he led the researchers of the transformation problem away from its scientific solution.

I have also shown that Samuelson was wrong to argue that after an inverse transformation, the profits of branches do not turn into surplus value. In this paper, I presented two methods for transforming production prices back into value. Using these methods, we allocate total profits across branches as surplus value. ${ }^{18}$

We have considered the so-called standard solution to the transformation problem and proved the fallacy of the redundancy thesis of the labour theory of value. According to Marx's conception, we regard the standard solution as a secondary analytical solution, which requires observing the invariance of the sum of the prices of the commodities, which form the final social product.

Thus, in this paper, I have presented a credible solution to the problem of value prices transformation. This solution proves that profit arises from surplus value, or rather from the newly created value generated by workers' labour and from no other source. The Holy Grail that Meghnad Desai wrote about, I found.

\footnotetext{
is conserved in exchange." (Mohun and Veneziani 2017, 1399). That means that the total net value-added in money is proportional to the total net value added in hours. Mohun (2018) argues that similar proportionality is characteristic of the total surplus value in money and hours. We agree with this in the original transformation. We violate this proportionality during the secondary conversion to preserve real wages. But even in this case, the total profit arises from the net value-added generated by the workers and from no other source.

${ }^{18}$ I presented methods of transforming prices into values for Marx's five-sphere model in a previous paper (see Kalyuzhnyi 2021).
} 


\section{Acknowledgments}

The author is grateful to thank Duncan Foley, Jean-Guy Loranger, Tiago Camarinha Lopes and Grigorii Pushnoi for very useful comments.

\section{Declaration of Conflicting Interests}

The author declared no potential conflicts of interest with respect to the research, authorship, and/or publication of this paper.

\section{Funding}

The author received no financial support for the research, authorship, and/or publication of this paper.

\section{Corresponding Author:}

Email: vvk1949vvk@gmail.com orvvkvvkvvk@ukr.net,orvvk1949@i.ua

\section{A note about the author}

Valeriy Kalyuzhnyi is an independent researcher (retired economist) living in Kharkiv, Ukraine. He has been Assistant Professor Department of Personnel Management and Labour Economics at the Kharkiv Regional Institute of Public Administration of the National Academy of Public Administration under the President of Ukraine and Deputy Director of the State Institute of Labour and Socio-Economic Research (Kharkiv). He holds 1982 a Ph.D. in economics from the Bardin Central Research Institute for Ferrous Metallurgy (Moscow).

\section{References ${ }^{19}$}

Alcouffe, Alain. 2021. Peter Fireman, winner of F. Engels" "Prize Essay Competition". The 14th Annual Conference of the European Society for the History of Tought, University of Amsterdam, Mar 2010, Amsterdam, Netherlands.

Blaug, Mark. [1962] 1985. Economic Theory in Retrospect. 4th ed. New York: Cambridge University Press.

Bortkiewicz, Ladislaus von. [1907] 1949. "On the Correction of Marx's Fundamental Theoretical Construction in the Third Volume of Capital." In Karl Marx and the Close of His System, 199-221. New York: Augustus M. Kelley.

Bortkiewicz, Ladislaus von. [1907] 1952. "Value and Price in the Marxian System." International Economic Papers 2. London: MacMillan. (This is the second and third of a series of 3 papers published under this heading in 1906-7).

Gehrke, Christian, and Heinz D. Kurz. 2006. "Sraffa on von Bortkiewicz: Reconstructing the Classical Theory of Value and Distribution." History of Political Economy 38 (1): 91-149.

Cogliano, Jonathan F. 2012. “Smith's 'Perfect Liberty' and Marx’s Equalized Rate of SurplusValue.” Working Paper 08/2011, New School for Social Research, Department of Economics. http://jonathancogliano.com/wp-content/uploads/2018/10/Cogliano-NSSR-WP082011- update2012.pdf

Desai, Meghnad. 2019. "A history of Marxian economic s 1960-2010. How we 'did' it." In Pluralistic Economics and Its History, 55-66. Edited By Ajit Sinha, Alex M. Thomas, London and New York: Routledge.

Fireman, Peter. 1892. "Kritik der Marx'schen Werttheorie.” Jahrbücher für Nationalökonomie und Statistik 3 (3): 793-808.

Foley, Duncan. 2011. I. I. Rubin and the Inverse Transformation Problem. Paper presented at the Russian Academy of Sciences, Institute of Economics: Round Table on I. I. Rubin, December 15, 2011. Moscow.

\footnotetext{
${ }^{19}$ You can press the $\longleftarrow$ key while holding down the left Alt key and return from the References into the text of
} the paper. 
Freeman, Alan. 2000. "Value, Price of Production and Market Price." Online at https://mpra.ub.uni-muenchen.de/6743/ MPRA Paper No. 6743, posted 15 Jan 2008 01:26 UTC

Glick, Mark, and Hans Ehrbar. 1987. "The Transformation Problem: An Obituary." Australian Economic Papers 26 (49):294-317.

Cogliano, Jonathan F. 2012. 'Smith's 'Perfect Liberty' and Marx's Equalized Rate of SurplusValue.” Working Paper 08/2011, New School for Social Research, Department of Economics. http://jonathancogliano.com/wp-content/uploads/2018/10/Cogliano-NSSR-WP082011- update2012.pdf

Kalyuzhnyi, Valeriy. 2006. "The Full Solution of a Problem of Commodity Values Transformation into Production Prices." https://www.researchgate.net/publication/352130571

Kalyuzhnyi, Valeriy. 2010. "Theory of Coupled Indicators of Productivity and Efficiency." Socintegrum. http://www.socintegrum.ru/Kalyuzhnyi_VV_9.pdf (in Russian)

Kalyuzhnyi, Valeriy. 2014. "Erroneous Arguments of Tugan-Baranowsky, Bortkiewicz and Steedman.” https://www.researchgate.net/profile/ValeriyKalyuzhnyi/publication/315406090

Kalyuzhnyi, Valeriy. 2021. "The Transformation Problem of Values into Prices of Production: Marx Errors or an Inattentive Reading of 'Capital'?." OSF Preprints. July 8. https://doi.org/10.31219/osf.io/tk43d

Kalyuzhnyi, Valeriy. 2021a. "New methods for the solution of the problem of transforming the values of the three-sector Bortkiewicz's model into original and equilibrium prices of production according to Marx's concept." https://cloud.mail.ru/public/wenc/6n73Zedg9

Kurz, Heinz D. 2018. "Marx and the 'Law of Value'. A Critical Appraisal on the Occasion of his 200th Birthday." Investigacion Economica 77(304): 40-71. https://doi:10.22201/fe.01851667p.2018.304.66399

Lopes, Tiago Camarinha. 2019. "The Transformation Problem of Values into Prices: From the Law of Value to Economic Planning." New Proposals: Journal of Marxism and Interdisciplinary Inquiry 10 (1): 29-42.

Lopes, Tiago Camarinha. 2021. "Content-Plurality and Political-Unity in the Debate on the Transformation Problem.” World Review of Political Economy 12 (1): 86-105.

Marx, Karl. 1987. Karl Marx, Frederick Engels: Collected Works, Vol. 25. New York: International Publishers.

Marx, Karl. [1857-61] 1986. Karl Marx, Frederick Engels: Collected Works, Volume 28. New York: International Publishers.

Marx, Karl. [1861-1863] 1989. Karl Marx, Frederick Engels: Collected Works, Vol. 31. New York: International Publishers. (Notebooks VII-XII of the 1861-1863 Economic Manuscript.)

Marx, Karl. [1861-3] 1991. Karl Marx, Frederick Engels: Collected Works, Volume 33. New York: International Publishers.

Marx, Karl. [1867] 1996. Karl Marx, Frederick Engels: Collected Works, Volume 35. New York: International Publishers.

Marx, Karl. [1885] 1997. Karl Marx, Frederick Engels: Collected Works, Volume 36. New York: International Publishers.

Marx, Karl. [1894] 1904. Das Kapital. Kritik der politischen Ökonomie. Dritter Band, zweiter Theile. Zweite Auflage. Hamburg: Otto Meissners Verlag.

Marx, Karl. [1894] 1991. Capital. A Critique of Political Economy. Book 3. Penguin.

Marx, Karl. [1894] 1998. Karl Marx, Frederick Engels: Collected Works, Volume 37. New York: International Publishers. 
Mohun, Simon, and Roberto Veneziani. 2017. "Value, Price, and Exploitation: The Logic of the Transformation Problem." Journal of Economic Surveys 31 (5):1387-1420.

Mohun, Simon. 2018. "A Celebration of the Labour Theory of Value.” Keizai Seminar, April: 24-30 (in Japanese) https://simonmohun.com/Papers/Japan_CelebLTV.pdf

Morishima, Michio, and Francis Seton. 1961. "Aggregation in Leontief Matrices and the Labor Theory of Value." Econometrica 29 (2):203-20.

Morishima, Michio, and George Catephores. 1978. Value, Exploitation, and Growth: Marx in the Light of Modern Economic Theory. London: McGraw-Hill.

Moseley, Fred. 2021. "A critique of Shaikh's two interpretations of Marx's 'transformation problem'.” Cambridge Journal of Economics 45 (3), 577-589, https://doi.org/10.1093/cje/beaa047

Nguyen, Dung. 1982. “Notes on Professor Samuelson's Analysis of the Marxian Transformation Problems." Southern Economic Journal 49 (1): 1-10. https://doi.org/10.2307/1058537

Pasinetti, Luigi L. 1977. Lectures on the Theory of Production. New York: Columbia University Press.

Ramos-Martinez, Alejandro, and Adolfo R. Herrera. 1995. "The Transformation of Values into Prices of Production: A Different Reading of Marx's Text." In Marx and Non-Equilibrium Economics, 1-28. Ed. Alan Freeman and Guglielmo Carchedi. Aldershot, UK and Brookfield, US: Edward Elgar.

Rieu, Dong-Min. 2006. “A Reexamination of the Quantitative Issues in the New Interpretation." Review of Radical Political Economics 38 (2):258-271.

Samuelson, Paul A. 1970. "The 'Transformation' from Marxian 'Values' to Competitive 'Prices': A Process of Rejection and Replacement." Proceedings of the National Academy of Sciences 67(1): 423-425.

Samuelson, Paul A. 1971. "Understanding the Marxian Notion of Exploitation: A Summary of the So-Called Transformation Problem between Marxian Values and Competitive Prices." Journal of Economic Literature 9 (2): 399-431.

Sandemose, Jorgen. 2016. "On the Exposition of the Transformation of Commodity-Values into Production Prices in the Third Volume of Capital - A Textual Analysis." Theoretical Economics Letters 6: 962-985.

Shaikh, Anwar. 1977. "Marx's Theory of Value and the 'Transformation Problem'." In The Subtle Anatomy of Capitalism, 106-139, ed. J. Schwartz. Santa Monica, CA: Goodyear.

Shaikh, Anwar. 2021. "Marx and the Other Sraffa: The Insignificant Empirical Effect of PriceValue Deviations on Economic Aggregates." In Velupillai K. (eds.) Keynesian, Sraffian, Computable and Dynamic Economics, 367-85. Palgrave Macmillan, Cham. https:// doi.org/10.1007/978-3-030-58131-2_16

Sraffa, Piero. 1960. Production of Commodities by Means of Commodities. Prelude to a Critique of Economic Theory. Cambridge: Cambridge University Press.

Steedman, Ian. 1977. Marx after Sraffa. London: New Left Books.

Sweezy, Paul M. 1942. The Theory of Capitalist Development. New York: Monthly Review Press.

Tugan-Baranowsky, Michael von. 1905. Theoretische Grundlagen des Marxismus. Leipzig: Verlag von Duncker \& Humblot.

Winternitz, Joseph. 1948. "Values and Prices: A Solution of the So-Called Transformation Problem." The Economic Journal 58 (230):276-280.

Wright, Ian. 2019. "Marx's Transformation Problem and Pasinetti’s Vertically Integrated Subsystems." Cambridge Journal of Economics 43 (1):169-186. 